Florida International University FIU Digital Commons

10-28-2008

\title{
I want out of the labels : how Chuck Palahniuk's characters challenge the dominant discourse
}

Jose Antonio Aparicio

Florida International University

DOI: $10.25148 /$ etd.FI14032326

Follow this and additional works at: https://digitalcommons.fiu.edu/etd

Part of the English Language and Literature Commons

\section{Recommended Citation}

Aparicio, Jose Antonio, "I want out of the labels : how Chuck Palahniuk's characters challenge the dominant discourse" (2008). FIU Electronic Theses and Dissertations. 1297.

https://digitalcommons.fiu.edu/etd/1297

This work is brought to you for free and open access by the University Graduate School at FIU Digital Commons. It has been accepted for inclusion in FIU Electronic Theses and Dissertations by an authorized administrator of FIU Digital Commons. For more information, please contact dcc@fiu.edu. 


\title{
FLORIDA INTERNATIONAL UNIVERSITY
}

\author{
Miami, Florida
}

I WANT OUT OF THE LABELS: HOW CHUCK PALAHNIUK'S CHARACTERS

CHALLENGE THE DOMINANT DISCOURSE

\author{
A thesis submitted in partial fulfillment of the \\ requirements for the degree of \\ MASTER OF ARTS \\ in \\ ENGLISH \\ by \\ Jose Antonio Aparicio \\ 2008
}


To: Dean Kenneth Furton

College of Arts and Sciences

This thesis, written by Jose Antonio Aparicio, and entitled, I Want Out of the Labels: How Chuck Palahniuk's Characters Challenge the Dominant Discourse, having been approved in respect to style and intellectual content, is referred to you for judgment.

We have read this thesis and recommend that it be approved.,
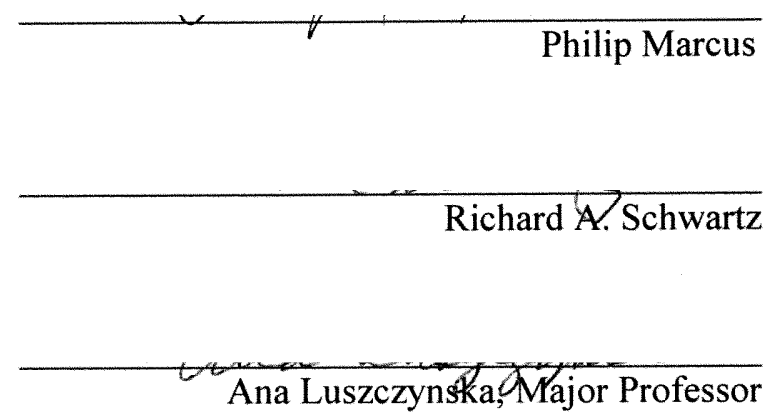

Date of Defense: October 28, 2008

The thesis of Jose Antonio Aparicio is approved.

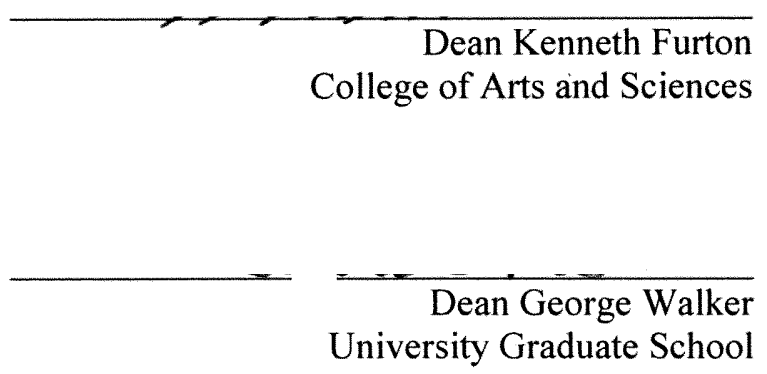

Florida International University, 2008 


\section{DEDICATION}

To my entire family: While I know they are proud of me, and I know they are glad I

finished this, I don't think they know why I keep doing it. Also, I'm sorry for all of the vacations, dinners, and other outings I missed while doing all of this.

To my Father, who might have been the one to really understand why I keep doing this. 


\section{ACKNOWLEDGMENTS}

"Nothing of me is original. I am the combined effort of everybody I've ever known."

There are many people that I owe much deep gratitude towards that made the completion of this possible. I would like to thank my major professor, Dr. Ana Luszczynska, who always forced me to "step back" and take a look at the material from new eyes and thoughts. I also want to thank her for throwing me into a deep existential crisis of which I spent many nights up reading, drinking, and smoking cigarettes, and many afternoons discussing the implications of my "identity" with fellow grad students and friends ${ }^{1}$. While I still have no idea "who I am," I now realize that that isn't such a bad thing. I now realize that having a "fixed" identity would be the worse fate.

I would also like to thank Dr. Richard Schwartz, who I felt was always over my shoulder looking at my topic sentences and paragraph structure. He has made me a better writer and has forced me to really put in care and thoughtfulness into everything I write (aside from this, this here that you are reading now, this is just words on a page, this is careless vomiting of thoughts and gratitude onto paper, but I feel that in giving thanks, gratitude, appreciation that it is fine to just say what comes to the heart and mind, and after writing this thesis, I just want to write, words, words, words. But words that let those who have helped me know that I know that they have helped me, and I want them to know that I am thankful for their help). I would also like to thank Dr. Schwartz for always telling me, "Well, why don't you try that and see if it works." He has always encouraged creative thought.

I would also like to thank Dr. Philip Marcus, who helped me look at literature in a new light and in new ways. Dr. Marcus always reminded his students that there are many ways to look

\footnotetext{
'I was going to name all of the "fellow grad students and friends," but then that list would be much too long, and I would inevitably remember a name I should have thanked after the fact, and by then it would be too late. Rather, all my "fellow grad students and friends" know who they are, which is why I use the Palahniuk quote to start this section. I have discussed what I am doing here with many people, all who, in their own way, have contributed to my thoughts and ruminations of the subject. And all those people-all my friends: I thank.
} 
at literature, and like blind men feeling an elephant and having very different experiences of the animal, literature needs to be looked at from many different angles. I have molested many elephants and books thanks to him. It was Dr. Marcus who would always say in the middle of his lectures, "Well, you don't need to know all of this, unless you want to do what I do." And I sat there and thought to myself, "I would love to do what he does. Getting paid to read and talk about what you read." No one told me there would be so much writing. But I don't mind the writing, and I quite enjoy the reading, and I also enjoy my day starting at two in the afternoon. Dr. Marcus has been a wonderful inspiration and has always been encouraging, and I can't thank him enough for all his help during the graduate school application process and in all his kind words.

I also want to thank Dr. Maneck Daruwala. When Dr. Milbauer (and thank you too, Dr. Milbauer, for being such a help and encouragement. I hope that I brought the reader to the text, as you always say) was being accepted and asked if I would like an assistance-ship, he informed me how I needed to thank Dr. Daruwala, who praised my genius and potential. I hope I don't let any of them down.

I would also like to thank my family. If I were to psychoanalyze myself, I wonder how much of me is doing this because of all those years growing up in which I saw my dad in his office typing away, writing books about Cuban politics and history. I'm only sorry to him for not reading more Cuban authors or knowing more Cuban history. I can only hope that he is in heaven (which means I hope there is a heaven) smiling down. I also want to thank my mom for reading me bedtime stories when I was a child. Also, for all the money, love, and support while I studied. I would write more here about thanking my family, but they got the dedication, so... They should know I love and thank them. And to my brothers who teased me for so many years as I was trying to find my way (they would always ask me, "When are you getting your degree? You've been in school for ten years?") Well, now I have two degrees; you guys should catch up.

I want to thank all my friends, who probably worried I was going to end up a general manager at a restaurant. A fine job (in which they would have gotten free food and drinks), but 
one they all know I wouldn't be able to stand. There is nothing better than at the end of a long day of "working" than to hang out and argue with them at Fox's. I would also like to thank all the friends I made along the way ${ }^{2}$.

I also want to thank Joffery's and all the hard working employees who kept me caffeinated for three years starting with my undergrad and on through two years of grad school. It was at Joffery's where the idea for this thesis was first put down on paper. I am saddened that Joffery's didn't last long enough so that I could have written my last words for this thesis there where it began.

And now that no one is reading this anymore, I also want to thank all the women who have turned me down in the last two and half years. Without your indifference towards my awkward advances, I would have never had the time to sit down and finish this thesis.

It is hard to believe that this is all coming to an end now, and the thing about it is that these pages will matter little, if at all, in a couple of years (if not weeks after it is all said and done-though it can never "all" be said and done), which is why I had fun with them (these pages). And in acknowledging all these people, I hope to show how intertextuality is not just in books but a part of life.

Thank You.

${ }^{2}$ See first footnoted in this section. 
ABSTRACT OF THE THESIS

I WANT OUT OF THE LABELS: HOW CHUCK PALAHNIU'S CHARACTERS

CHALLENGE THE DOMINANT DISCOURSE

\author{
by \\ Jose Antonio Aparicio \\ Florida International University, 2008 \\ Miami, Florida \\ Professor Ana Luszczynska, Major Professor
}

The purpose of this study was to explore postmodern identity in the work of Chuck Palahniuk. The characters within Palahniuk's text Invisible Monsters realize the manner in which identity is a construct, and their response is to oppose and redefine it. In my research, I looked at how postmodern identity is defined by some of the leading critical thinkers in the field, and then I applied their thought to Palahniuk's characters. I showed how these characters come to understand the process by which society defines them, and with that realization, they oppose its totalizing definitions. The characters deconstruct the natural attitudes society has towards identity, and they reveal that it is in some way possible to create a unique identity that is not easily definable by the ruling discourse. I concluded that his attention to identity highlights Palahniuk's concern for the place, identity, and influence of his generation. 
TABLE OF CONTENTS

CHAPTER

PAGE

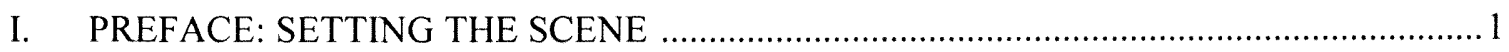

II. INTRODUCTION: A NECCESARY CONTRADICTION ……….................................

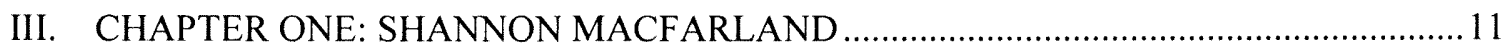

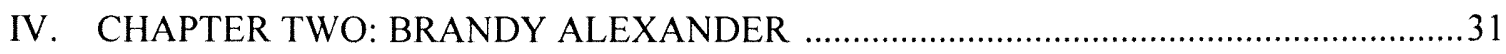

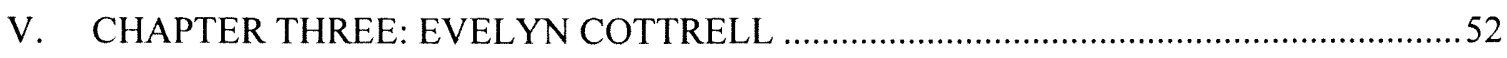

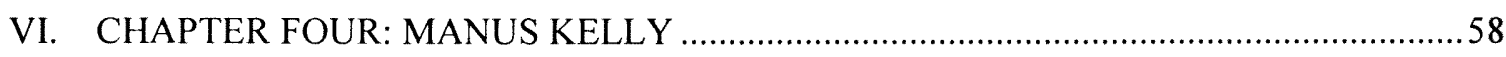

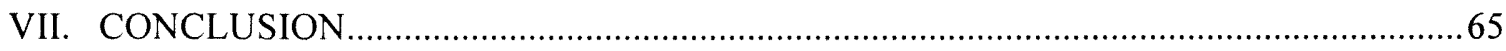

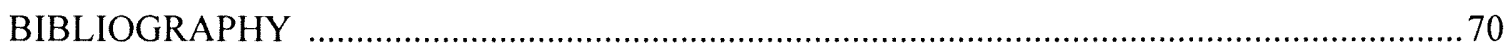




\section{Preface: Setting the Scene}

This is called scene setting: where everybody is, who's alive, who's dead (Palahniuk Invisible Monsters 11).

There are no such things as monsters (they are invisible), but you fear them like they are real. The monsters in your closet or under your bed will follow you around for the rest of your life. They will live in your mind-invisible-but giving you real fear. Even as adults, we fear the (invisible) monsters of our childhood: the bogeyman, the dark, death, disease, government, God, and these all become neurosis. It is this concept of monster that finds its way into Chuck Palahniuk's novel. The invisible, which can be translated as being trapped by what is seen or the enclosure (in) of the seen (visibilis), and it is what is seen ${ }^{1}$ that will trap the characters. This novel is about what Chuck Palahniuk believes is not public knowledge (invisible), which is that society is the real monster hiding under the bed, in the closet, lurking at every corner. The monster is society that inspires horror and disgust in the characters of the novel.

The invisible monster is not just the main character who disfigures herself and gives up her identity so that she can become invisible from society. It is the unseen monster of society and hierarchal, patriarchal authorities and their discourse that defines [defined] who she is. The monster in the novel is the false dichotomy, which privileges beauty, vapidness, and outer looks at any cost, while at the same time claiming purity. The social systems in place privilege presence as long as it is not a woman's presence, and it is this monster that the protagonist of Invisible Monsters fights when she goes to sleep and dreams of who she can become, and of how she tries to define her identity while she tries to figure out a way to kill the monster lurking-watching her-in her closet, under her bed.

\footnotetext{
${ }^{1}$ What the characters see surrounding them-society defining them and trying to control them-will be one of the monsters they have to deal with and try to break free from, and rather than be trapped by what they see, they will become "monsters" in order to not be seen by society.
} 
My contention is that in Chuck Palahniuk's work, the main characters come to a foundational apprehension that their identities and choices in life are all organized by artificial, social constructions (invisible monsters), especially the construction of language. Upon achieving this realization, they deliberately disfigure and otherwise alter themselves or otherwise challenge the discourses ruling their lives in order to break free of their socially imposed identity. Ultimately realizing that they cannot escape the system that they are entrenched within, they are forced to operate within the very system they want to escape, but they will deliberately seek to compromise the pattern of binary oppositions that underlie the patriarchal social constructions that are constraining them ${ }^{2}$.

Most of the criticism about Palahniuk has focused on masculine identity or the violence of, specifically, Fight Club. Masculinity, masochism, and violence have been interpreted in different ways by different scholars, such as Slavoj Zizek's ${ }^{3}$ or Alexander Boon's ${ }^{4}$ or J. Michael Clark's ${ }^{5}$ analyses. However, rather than look at Fight Club through some type of masculinity study, hidden homoeroticism, study of violence, consumerism, masochism or other such covered topic of Palahniuk, I want to look at Palahniuk's other work Invisible Monsters through poststructuralism, or more specifically, I want to use postmodern theory to first show how the

${ }^{2}$ This idea is found in Derrida and what he calls the "undecidables." Undecidables are terms (in the case of this novel, people) that do not encompass either/or in the set of binaries. Undecidables are terms that can be both and neither of the terms - and they threaten the "naturalness" of the dominant discourse that wishes to put everything on one side of the binaries exclusively.

${ }^{3}$ Zizek looks at masochism using his Marxist-Lacanian approach, though more Lacanian in this case than Marxist. He does a close reading of the scene in the movie in which the unnamed narrator of Fight Club beats himself in front of his boss fulfilling a subconscious wish the boss had towards the narrator.

${ }^{4}$ Boon's article deals with white heterosexual males 'identity crisis' in a culture that rewards the "masculine" man while condemning violent behaviors; thus leaving men with "... a nostalgia for displaced traditions" (Boon 267).

${ }^{5}$ Clark has an interesting thesis: "...the essay pushes beyond deconstructive criticism to explore "green" alternatives - at once returning to the masculinity/economics issues in popular culture, insisting on the need for both an economic theory and a value system that do not reduce all value to monetary terms, and seeking a renewed commitment to relational justice in ecosystemic communities" (abstract). 
characters in the novel realize the logocentric discourse at work in society and affecting their identities, and then show how Palahniuk's characters deconstruct and challenge these notions.

Whether it is women reversing the order of patriarchal society, or society's "failures" (the anti-hero) holding a mirror up to society's hypocrisy, or characters dealing with issues of identity, Palahniuk uses a post-structuralist linguistics lens to critique society and the binaries constructed by what society terms "normal."

Jacques Derrida uses deconstruction to display how Western metaphysics endeavors to proclaim full presence of meaning; that is to say, how Authors wish to show how words and theories mean exactly what their author intended, denying the ambiguous and productive nature of language. Palahniuk - aware of the ambiguous nature of language $e^{6}$-substantiates that Western society privileges an economy of exchange, possessions, and societal status while simultaneously indicating a rejection of these societal norms for the second, lower term of the binary opposition ${ }^{7}$.

In post-structuralist thought, language and meaning are shown to be ambiguous because of the arbitrary nature of the sign system language and meanings are based. In general, the ruling discourse society is embroiled in wishes to have direct access to meaning; whereas one can see that this direct access to meaning is purely ideology. As Eagleton, deftly summarizing Derrida, explains:

There is no concept which is not embroiled in an open-ended play of signification, shot through with the traces and fragments of other ideas. It is just that, out of this play of signifiers, certain meanings are elevated by social

\footnotetext{
${ }^{6}$ Throughout his novels, Palahniuk is constantly reminding the reader how language and the way we think of reality is just a construction: "This is better than real life" (Fight Club 22). "Nothing is static" (Fight Club 49). "What happens in fight club doesn't happen in words" (Fight Club 51). His characters are aware that words are not static, and that words are only arbitrary constructions.

${ }^{7}$ Just as Derrida points out that language is used by society in constructing these binary oppositions, Palahniuk's characters will show how they use the knowledge of this construction in order to challenge the binary structure of the dominant discourse.
} 
ideologies to a privileged position, or made the centres around which other meanings are forced to turn (Eagleton 114).

The characters in Invisible Monsters will show how they realize that they are part of this system. They will show how this is a system which 'elevates by social ideologies' not only meanings, but people and what people 'mean' or signify. There is a dichotomy that arises out of this ideology that privileges certain discourses and meanings over others, and Palahniuk's characters will deconstruct society's definitions and meanings showing how the privileged term is not inherently better or superior to the term that society believes to be debased or inferior. That is, Palahniuk's characters will deconstruct society's definitions of gender, beauty, love, and social status to name a few. His characters will embrace and then reject these definitions in order to show society that these definitions are merely constructions of social ideology and discourse and not naturally inherent in the words and concepts themselves.

In Palahniuk's work, characters are aware of these dichotomies and the way that language is just, "a copy of a copy of a copy" (Palahniuk Invisible Monsters $\left.{ }^{8} 14\right)$, and they will deconstruct their lives, language, and the societies they are members of to nullify the idea of a designated "second" term that is held in lower esteem compared to the privileged "first" term and to show how there is not a "natural" ruling logic to the way society has constructed popular ideas of identity. Society creates power structures by controlling meaning ${ }^{9}$. But Palahniuk's characters, by realizing how language is just "a copy of a copy," can deconstruct the meanings imposed by the ruling ideologies.

Many of Palahniuk's characters redefine themselves not only by realizing the implications of language and society but by physically redefining themselves through sex

\footnotetext{
${ }^{8}$ Herein referred to as $\underline{I M}$

${ }^{9}$ An extreme example of this concept is the Nazis controlling the meaning of what a "pure race" is. Another example is the way society imposes meaning on material objects; for instances, a Rolex watch or BMW car "means" (signifies) high social status and class.
} 
changes, facial disfigurement, and embracing alternative lifestyles. They have become conscious of their situation in society ${ }^{10}$. They ascertain how language is all around them, always- already defining and suppressing them ${ }^{11}$. They will use this knowledge to challenge the definitions, power, identity, and the dominant discourse that society impresses on them, and they will redefine this discourse in order to create a new one; furthermore, in $\underline{I M}$, Palahniuk's characters are aware of the danger of replacing one discourse for another and will try to avoid this quagmire by constantly changing the story in order to try to avoid any fixed definitions ${ }^{12}$. Any fixed definition would assume naturalness and direct meaning that they are trying to oppose and is impossible because there are no concrete and fixed meanings.

I will demonstrate how Palahniuk holds a mirror up to the post-modern world we live in, which is characterized by a society of consumers who privilege aesthetic beauty and condemn alternative lifestyles. Palahniuk uses his anti-heroes to dispute social norms. Palahniuk maintains in Fight Club that, "Our Generation has had no Great war, no Great Depression. Our war is spiritual. Our depression is our lives"(149); in other words, without anything in this generation to define it, what does define the generation is material possessions and spiritual bankruptcy. Palahniuk opines that we have been conditioned by society to want all the "wrong" things and cope with our existential anxiety in all the "wrong" ways. He is important to study for the same

\footnotetext{
${ }^{10}$ Palahniuk discusses how he became aware of discourse, 'the story,' affecting society. In a documentary, he talks about the moment when a writing workshop friend, Tom, told Palahniuk to write the way he talks, and Tom also told Palahniuk that Palahniuk could be one of the people who affects society, who dictates culture, and Palahniuk says that, "up until that moment, for a kid growing up in the desert... it had never dawned on me that people control the culture" (Postcards from the Future).

"As Eagleton explains: "It is not that I can have a pure, unblemished meaning, intention or experience which then gets distorted and refracted by the flawed medium of language: because language is the very air I breathe, I can never have a pure, unblemished meaning or experience at all" (112-113). This sense of being trapped is seen in Shannon's internal dialogue: "The thing about being cloned from all those shampoo commercials... We're all such products" (Palahniuk IM 12). There is the sense of being trapped because the characters realize that their identity is just a copy, a clone of capitalist discourse, and that they are just products of the products they buy - which is ruled by meaning/language imposed by social ideologies.
}

${ }^{12}$ Ultimately, they come to realize that there is no getting out of the system, so they will continue to challenge the "normal" definitions set up by society. 
reasons Fitzgerald or Hemingway are important to study - he gives us a glimpse into our era, our spirit, and our dependence on fitting into social norms.

Through a close critical analysis of $\underline{I M}$, I want to show how Palahniuk is concerned with the discourses that rule our lives. Palahniuk shows us that it is stories (language) that we are made up of, and if we can realize that we are the stories we live, then why not control that story and becomes whatever we want to become ${ }^{13}$. Furthermore, Palahniuk uses violence and other shocking subject matter in his novels, but in the end, what is left is the connection between two people or a love story. It is in this manner that I will fill the critical gap that is missing in the theoretical discussion of Palahniuk's oeuvre, and show that Palahniuk is much more than the author of Fight Club. He is an up and coming author with great satiric wit and a trenchant social commentator.

\footnotetext{
${ }^{13}$ The way to control the narrative is to be the author of the story rather than let society write a controlling story. By being the author, the individual can control the definitions and try to change his or her situation. A problem arises with this method because in writing a new discourse, a new story to live by, it leaves the new story open for interpretation, but this is why Palahniuk's characters are going to constantly change the discourse and constantly write a new story. The characters try to avoid any fixed, static definitions by constantly changing the definitions and the story.
} 


\section{Introduction: A Necessary Contradiction}

From the viewpoint of a fore-ward, which recreates an intention-to-say after the fact, the text exists as something written - a past - which, under the false appearance of a present, a hidden omnipotent author (in full mastery of his product) is presenting to the reader as his future. Here is what I wrote, then read, and what I am writing that you are going to read (Derrida Dissemination 7).

To say in this thesis that the characters in Chuck Palahniuk's work are aware of their constructed identities and challenge those identities - is using the same logocentricism that the characters are challenging-and seems to be a contradiction, but as will be shown, it is a contradiction that is impossible to escape. Furthermore, I feel I am cheating the central point of my thesis by using a standard style of analyzing and writing about a text that challenges standard styles and systemized organization. But there is no other way. Whenever an interpretation is performed, there are different ways of performing-or different interpretations of - the interpretation. As Derrida points out, one way to interpret "seeks to decipher" and find the origin of things (Derrida Writing and Difference 292). Then there is a style that, "affirms play and tries to pass beyond man and humanism" and find the foundation and the conclusion of play (Ibid.). The other interpretation of interpretation does not seek an end or final origin. I try, in the most organized way possible, to show how these characters are in a world without organization; in other words, I do not seek an end or an origin, for the world is much too chaotic to find that origin even if there was one. Like the protagonist, Sarah Mcfarland, I could never get to the origin because, "Nothing of me is original. I am the combined effort of everybody I've ever known" (Palahniuk $\underline{I M} 104)$. This, that you are reading, is organized because that is the way that society says it has to be. This is an organized analysis of disorganized lives. 
The protagonist of the story, Shannon Mcfarland, warns against such logocentric organization:

Don't expect this to be the kind of story that goes: and then, and then, and then.

What happens here will have more of that fashion magazine feel, a Vogue or a Glamour magazine chaos with page numbers on every second or fifth or third page...

Don't look for a contents page, buried magazine style twenty pages back from the front. Don't expect to find anything right off. There isn't a real pattern to anything, either. Stories will start and then, three paragraphs later:

Jump to page whatever. Then jump back...

And you really, really need to get used to that feeling, here, on the freeway, at work, in your marriage. This is the world we live in. Just go with the prompts (Palahniuk IM 20-21).

Shannon Mcfarland will narrate the story in this chaotic, jump/cut manner as she is aware of the constructed logic which rules her society and her reasoning, and she will, therefore, try, from the beginning of the text (which is narrating the end/beginning of her story), to avoid using any kind of constructed reason or logic to tell the story of how she will challenge these logocentric constructions. A straightforward linear chronology is seen as a construction. It affords time, an abstract concept, the privilege of presence. Looking at Heidegger, one can see how his concept of Being-in-the-world analyzes historical time. Historical time or linear chronology treats the past as a series of objectified events, but being is always moving forward towards its possibilities. It is be-coming or projecting ahead; therefore, history should be thought of as Dasein's encounter with the past only to see its possibilities in the present. The past is also present and future possibilities, which means that this chronology should not be seen as a linear study of events, causes, or collected facts. The events that make up the historical, linear past are 
better seen in Shannon's jump/cut manner in order to analyze the present and future possibilities and not as a series of objective, linear facts.

Additionally, she realizes that her identity is caught up in this chaos as well, and because she cannot ever be fully present to herself in any fixed way, she realizes that she is going to have to "get used to that feeling" of always missing something. Shannon cannot be fully present to herself because the structure of being is one in which being is always moving forward (alwaysalready being-there) in search of its possibilities. Being is a throwness into the world, which keeps it from being a fixed, static entity.

She is, after all, the model. And $a$ model is a three dimensional representation of the original on a smaller scale in order to be reproduced. But what is she the model of? Certainly more than for fashion wear. It can be said that she is the model postmodern woman. Shannon is aware of the language games around her, defining her, and furthermore, she is the model of the postmodern eclecticism, “...one listens to reggae, watches a western, eats McDonald's food for lunch and local cuisine for dinner, wears perfume in Tokyo and 'retro' clothes in Hong Kong"' (Lyotard 76). Also, she is the model Derridian undecidable: she wants to be copied, and she herself is clearly a copy of constructed societal ideals of aesthetics, while at the same time she wants to be invisible; she wants to be seen and unseen, the center of attention and the invisible monster. She wants salvation in mayhem; she wants to lose herself in order to find herself. Shannon wants to show how one term is always implied and undermining the other term in a set of binaries.

Rather than follow the typical discourse, which says that one has to "find oneself," she will do the opposite of what has been fed to her throughout her whole life. Rather than be saved, Shannon, as well as the other characters, will make the biggest mistakes they can think of making in order to break free from (try to break free from) the society that has imprisoned them. Shannon knows that since there is no origin that: 
No matter how careful you are, there's going to be the sense you missed something, the collapsed feeling under your skin that you didn't experience it all. There's that fallen heart feeling that you rushed right through the moments where you should've been paying attention (Palahniuk IM 22).

Since we are wrapped up in language and unable to escape it, there will always be a feeling that something is being missed:

... since language is something I am made out of, rather than merely a convenient tool I use, the whole idea that I am a stable, unified entity must also be a fiction. Not only can I never be fully present to you, but I can never be fully present to myself either (Eagleton 112).

Therefore, rather than search for a logocentric idea of "salvation," Shannon will show how she and all the characters have the awareness of not being able to be fully present to themselves nor to anyone else, and they will challenge (the best they can) logocentric ideas of identity. They will, furthermore, challenge ideas of salvation and Western ideas of how "character" (identity) is constructed by trying to do the opposite of what is thought to be "normal." Shannon will not only be the model, she will also be the archetype: a system to be imitated and followed. She wants to become like the prisoner who breaks free in Plato's cave and is trying to get the rest of the inhabitants to turn around to see the world behind them. The problem is, of course, that in this allegory, the world behind them are just other versions of the shadows in front of them. The question then becomes: how can one challenge the dominant discourse that rules and defines them when they are trapped within the system? The answer for these characters seems to be to change the discourse as much as possible in order to try to avoid becoming stagnant and fixed. 


\section{Chapter One: Shannon Mcfarland}

I have to say the three most worn-out words you'll find in any script. Just the words make me feel like I'm severely fingering myself. They're words is all. Powerless. Vocabulary. Dialogue (Palahniuk IM 18).

Shannon realizes how her being is bound up with society, and thus society is creating her being $^{14}$. But she realizes that within this tautology that the societal influences around her are only texts to be interpreted rather than intrinsic realities. She knows that her life is just a "story" to be interpreted; she is immersed in and a part of discourse. For post-structuralism and deconstruction, it is not that Shannon's life is inaccessible to us or unimportant to us, but rather that her life is a text and thus open to interpretation. Furthermore, there is no origin from which to start, and consequently the story will not follow a logical progression of "and then, and then." Shannon is indicating to her audience that she is bound up in language and that we are only getting a "story" of her lived experience. This story does not hold a direct meaning that the reader can get to; it is just a story that will be interpreted. Hence, in order to get out of the discourse that is defining her, she tries to disfigure her face, which leaves her incapable of speech. Now unable to speak, she lets others interpret her life for her because it has been only through language that she knew how to define herself and knows who she is.

After her brother's accident, Shannon comes to an initial realization that others define her. Her family defines who she is and validates her identity. She says as much:

I could've not called the police all those times to suggest that Shane's accident wasn't. What stands in my way is the story [sic]how Shane burned my clothes.

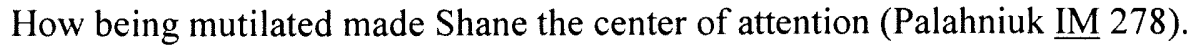

\footnotetext{
${ }^{14}$ This boundness is meant in a Heideggerian sense, in which part of the structure of Dasien is Being-withothers, which leads Dasein to following the 'they': "This being-with-one-another dissolves one's own Dasein completely into the kind of being of "the others" in such a way that the others, as distinguishable and explicit, disappear more and more" (Heidegger 119). When I say that these characters want to break free from societal constraints and definitions, an underlying meaning of that will be that they want to break free from the "they" influence around them that dissolves their unique Dasein.
} 
The situation only gets worse when Shane is presumed dead by AIDS; in his absence, he becomes more of a presence for the family. This notion of something absent being present is the same notion of the trace that Derrida explains, "Derrida takes the notion of 'trace' as a mark of something absent that has never actually been present" (Moran 469). Shane, like Shanoon, has never nor can he ever be fully present because his being is constituted within language. There can never be any fully-present being (as footnote 11 points out). Furthermore, Shane's presence, especially after his parents found out he was gay, becomes an enigma-something the family ignores because Shane is shameful to them, and this is why he is both present and absent. Additionally, Derrida elucidates the concept of carrying the world of the other after the other's death. First, Derrida explains that in order for there to be a dialogue between two people there needs to be an interruption; he then goes on to explain how after the death of the other, the world of the other is carried on by the survivor:

Hence mourning no longer waits. From the first encounter, interruption anticipates death, precedes dearth. Interruption cast over each the pall of an implacable future anterior. One of us will have had to remain alone. Both of us knew this in advance. And right from the start. One of the two will have been doomed, from the beginning, to carry alone, in himself, both the dialogue, which he must pursue beyond interruption, and the memory of the first interruption (Derrida Sovereignties in Question 140).

With Shane dead to the family, they carry his world, and he is more present than ever. The family feels the absence of the brother who was never actually present. The nostalgia the parents have for their dead, gay son is mixed between the son they loved: the basketball player, and the son they neglected: the gay, scarred son, dead of AIDS. Of course, this is just the "story" that stands in the way for Shannon. It is this story that makes Shane the center of attention and is the first "story" that Shannon wishes she could change in order for her to be the center of 
attention. If Shannon had not called the police, then the story would be different. The way the story was for Shannon was that "They [her parents] liked my brother more because he was mutilated $^{15, "}$ (Palahniuk IM 72). For Shannon, the narrative was that her brother was better loved because he was mutilated, but that discourse changes when the brother turns out to be gay and dead from AIDS, "'Still there is a happy ending.'[...]'He's dead now"” (Ibid. 73). Noticeably, what Shannon is saying here is just an interpretation of her and Shane's/Brandy's account. This is Shannon's story before she realizes that Shane has changed the plot; subsequently, in a sense, Shane really is dead because his/her story has been changed and is now Brandy Alexander's narrative.

With Shane absent and the family neglecting her, Shannon hungers for some attention since it is through attention that she knows who she is. It is only when totalized and when she has been put into words that she gets a sense of self. As it is only through representational language that we can have a discursive or logical understanding of any object of analysis, whether it be of self or not ${ }^{16}$. Shannon's yearning for attention is seen when she comes home for Thanksgiving and all her parents do is talk about Shane, "We're supposed to sit and eat with Shane dead all over the table in front of us" Shannon says (ibid. 91). This constant talk of her dead brother, with no talk about her-her life, career, boyfriend-is the reason she wants to break free from her parental constraints, or at least, have her parents make her the center of attention and have them talk about her:

\footnotetext{
${ }^{15}$ Even before the brother was 'dead from AIDS,' he was the favorite, basketball-playing son, so Shannon has always wanted the attention.

${ }^{16}$ Heidegger explores how entities exist in language. It is only through language that one can get a sense of beings in the world. While things may exist in the world before there is a word for it, it does not exist in the same way once it has been put into words. If Shannon's parents are unable to talk about her, then her being is not represented/acknowledged by her parents. The later Heidegger will discuss an "essential language" that can name being; a language he refers to as "poetry."
} 
Now what I wanted my folks to talk about was me. I'd tell them how Evie and me were shooting a new infomercial. My modeling career was taking off. I wanted to tell them about my new boyfriend, Manus, but no (Ibid. 93).

It is important to notice all the things she wants to tell her parents are things that define identity: work, relationships (within relationships: gender), and friendships. One's conception of identity comes from those around us. Heidegger, in Being and Time, discusses how being is bound up with society (history, language, etc), and Being-in-the-world-towards-others-towardsdeath is a phrase Heidegger uses to show the bound-up relationship of all these factors influencing identity/being ${ }^{17}$ :

...Being-in is not a 'quality' which Dasein sometimes has and sometimes does not have, without which it could be just as well as it could with it. It is not the case that human being 'is,' and then on top of that has a relation of being to the 'world' which it sometimes takes upon itself. Dasein is never 'initially' a sort of a being which is free from being-in, but which at times is in the mood to take up a 'relation' to the world. This taking up of relations to the world is possible only because, as being-in-the-world, Dasein is as it is. (Heidegger 53-54).

This is to say that being is, radically, in an a priori fashion, engaged and influenced by the world; therefore, Shannon's being (her identity) is bound up with these things she wants to talk about: work, relationships, friendships. Moreover, she needs to talk about her life, put her experiences into words, in order for these things to be real for her. Since the family is such a part of identity, without being able to share her experiences with her family, she is unable to validate her identity and experiences. Shannon wants to tell her story in order for it to become real. This motif is seen throughout Palahniuk's novels. He says, "Life never works except in

\footnotetext{
${ }^{17}$ For a more complete discussion of these concepts see: Being and Time, or for a simpler discussion of these concepts see Moran's discussion in Introduction to Phenomenology.
} 
retrospect...since you can't control your life, at least you can control your version" (Palahniuk, Stranger Than Fiction 205). Additionally, this need that Shannon has to share her life is another common topos found in Palahniuk's work as Antonio Casado de Rocha points out, "The characters in Palahniuk's fiction usually have an unorthodox approach to life, but their main goal is quite straightforward-to find a way to live together with other people" (105).

Shannon's parents ignore Shannon and talk of her ambitions, which leads Shannon to contemplate who she is; moreover, if who she is, is only what others think of her, then her parents refusal to talk about her means that she gets no validation of what her identity might be. In addition, Shannon's parents tell her, "It's not that we don't love you [...] it's just that we don't show it" (Palahniuk IM 96), but if they do not show it, then Shannon has no way to know that it is true. This situation might be what gives Shannon the initial realization that identity is constructed through and by society (parents, work, relationships, culture, historical context, etc), and this is the reason that Shannon, in an attempt to subvert those definitions, resorts to mutilation in order to try and break free from these societal impositions. Palahniuk talks about subverting discourse ("the story") in a documentary film. He says that the only way to change the way society thinks is to change the story:

Do you want to keep living the way you've been living, or do you want to be aware of how you are living and in that awareness chose a different way to be. (Postcards from the Edge)

In this subversion, though, she feels guilt:

Sorry, Mom.

Sorry, God (Palahniuk IM 42). 
What the reader comes to realize about Shannon is that she is a bad person who, nonetheless, wants to change and feels guilt ${ }^{18}$. Shannon is selfish, but she is selfish because she has been conditioned to think that only society can define her, and society has defined her as merely a pretty girl who wears pretty clothes. It is because of this that she feels guilt when she has not lived up to the expectations of society, which is represented in her mind by God and her parents to whom she apologizes. Society dictates who she is, so of course, she will be selfish and needs the defining and judging eyes of others in order to feel a sense of self. While this is problematic because, in a sense, it is hard to escape this selfishness, Shannon tries to find a way out of the problematic; if society defines selfishness, then it can be said that any seemingly altruistic act is really only done so that society can deem the person altruistic, in other words, people are altruistic for selfish reasons, but again, Shannon attempts to break free from societies definition of selflessness by giving up her identity and expecting nothing in return.

When she is working, Shannon further realizes other hegemonic discourses besides her parents, which define her. As a model, Shannon is defined by her work, and her work defines who she is. This tautology goes beyond the concept of actions (her work) defining her identity. As a model, not only is Shannon part of an advertising discourse used to sell products, she is also a part of the society that is defined by its products. Shannon puts it simply, "We're all such products" (Palahniuk IM 12). Baudrillard illustrates how material objects come to define subjectivity ${ }^{19}$ :

\footnotetext{
${ }^{18}$ She is bad even if she is within the inescapable, constructed narrative of society. Whether she is held to an existential idea of morality, in which she comes up with her own moral code, she, herself has deemed herself selfish and bad. She can also be seen as bad when Baudrillard's argument is taken into account. Shannon is helping proliferate the idea of social worth being measured by material possessions and social status. Another way to look at how she can be seen as bad is because she does not take into account the other. There is, as the reader learns at the end of the novel, an ineffable standard to follow, which for Shannon will be love.
}

${ }^{19}$ The idea of society defined by its products is also one that is found in Fight Club. 
...objects are categories of objects which quite tyrannically induce categories of persons. They undertake the policing of social meanings, and the significations they engender are controlled. Their proliferation, simultaneously arbitrary and coherent, is the best vehicle for a social order equally arbitrary and coherent, to materialize itself effectively under the sign of affluence (Baudrillard, emphasis in orginal 20).

Baudrillard argument is that we are defined and placed into categories by what we own, and the objects we own create a hierarchy; therefore, the things we own defines who we are and where we are in the constructed societal hierarchy, so it becomes society, itself that constructs the terms by which to define itself and ultimately alienate itself. "We're all such products." This idea is scattered throughout the novel: Brandy is described as “... wearing this sleeveless Versace kind of tank..." (Palahniuk IM 57), also, "Evie would be wearing this little black cocktail number with an asymmetrical hemline satin skirt and a strapless bodice by Rei Kawakubo" (Ibid. 155); again "Brandy... wearing this strapless metallic bodice sheath as pink as the burning center of a road flare with a bejeweled bodice and a detachable long silk taffeta cape with balloon sleeves" (233), and there are other moments in which Shannon describes other characters by what they are wearing-by material objects—and it is the material objects that define the people. Shannon has been indoctrinated into this system by society; hence, the way she describes other people is through the fashions that they wear. Shannon, as a model, is put into a hierarchical order in terms of her job based on a similar system. She has not attained the level in her job where she is a highend model shooting in exotic locations; rather, she is on the lower end of the modeling world and is forced to model the lower end fashions. Consequently, the fashions that Shannon models are put in comparison to ugly places ${ }^{20}$ :

\footnotetext{
${ }^{20}$ This is an example of intertextuality (as will be discussed later) where meaning is achieved by way of content, or as Derrida says, "This interweaving results in each 'element'... being constituted on the basis of
} 
The uglier the fashions, the worse places we'd have to pose to make them look good. Junkyards. Slaughterhouses. Sewage treatment plants. It's the ugly bridesmaid tactic where you only look good in comparison. One shoot for Industry JeansWear, I was sure we'd have to pose kissing dead bodies (Palahniuk IM 163-164).

This is how society creates needs for itself. Shannon is part of an advertising system that creates phantom needs for society - society then believes that it can only attain status through the objects it consumes:

Within "consumer society," the notion of status, as the criterion which defines social being, tends increasingly to simplify and to coincide with the notion of "social standing." Yet "social standing" is also measured in relation to power, authority, and responsibility. But in fact: There is no real responsibility without a Rolex watch! Advertising refers explicitly to the objects as a necessary criterion: You will be judged on...An elegant women is recognized by...etc (Baudrillard 22).

Shannon is part of this system creating needs for society, but she is also alienated by the system because she is controlled by the system she is perpetuating by her job. She will not have "made it" as a model until she no longer has to pose with dead meat, but she will only show her status of being a model that does not have to pose with dead meat if she encompasses what the fashion discourse deems as high class.

Shannon's job defines who she is as well as constructs the way she is going to be in the world, and that world (the world of her job) is one in which Shannon was defined by what males told her to feel:

the trace within it of the other elements of the chain or system. This interweaving, this textile, is the text produced only in the transformation of another text. Nothing neither among the elements nor within the system, is anywhere ever simply present or absent. There are only, everywhere, differences and traces of traces" (26-27). 
Most of my adult life so far has been me standing on seamless paper for a raft of bucks per hour, wearing clothes and shoes, my hair done and some famous fashion photographer telling me how to feel.

Him yelling, Give me lust, baby.

Flash.

Give me malice.

Flash.

Give me detached existential ennui.

Flash.

Give me rampant intellectualism as a coping mechanism (Palahniuk IM $13)$.

One sees, in this inter-textual $\left.\right|^{21}$ quote, many of the problems of identity and where/how identity is constructed by a male dominated discourse and by the economy of production. The fashion photographer is telling her how to feel, and the two main emotions that come out are 'lust' and 'malice' which plays up to the femme fatal stereotype and male fantasy of a dangerous and beautiful woman. Then Shannon's thoughts weave into the text while she wishes for existential ennui and rampant intellectualism as a coping mechanism. Existentialism tells us that we have to define ourselves though our actions by controlling our emotions, which indicates that for Shannon, this existential thought is only intellectualism used in order to cope in society, and she is bored with controlling her emotions and her existential question of being - she knows that she "is", but she does not know how that "is" is defined. The problem is that there is no getting

\footnotetext{
${ }^{21}$ Inter-textuality is itself a postmodern topos. Everything gains meaning from relation to other text, and all text are shaped by other text that preceded it. All meaning, therefore, comes from seeing the relationships between text and by recognizing that nothing has meaning in itself. Saussure says, "These signs thus function not according to their intrinsic value but in virtue of their relative position" (116). If meaning comes only through the text's context, then Shannon only gets her "say," her words "detached existential ennui,' through the relationship that the words of the photographer says. His commands, in a sense, give Shannon's words meaning. And words are what define identity, so Shannon is defined by the commands of the male, dominant, patriarchal society.
} 
out of society in order to define one's self objectively as Brandy explains to Shannon, "We're so trapped that any way we could imagine to escape would be just another part of the trap. Anything we want, we're trained to want" (Palahniuk IM 259). Derrida echoes this problem of not being able to get outside of discourse in order to question discourse when he is looking at the work of structuralist: any comment on discourse becomes a discourse:

There is no sense in doing without the concepts of metaphysics. We have no language - no syntax and no lexicon-which is foreign to this history; we can pronounce not a single destructive proposition of precisely what it seeks to contest (Derrida Writing and Difference 280).

Shannon has been defined by her society and cannot completely escape that society to define herself outside of societal terms. The famous fashion photographer, for instance, is part of the male patriarchy and is the one giving Shannon directions: "Him yelling." The male dominated society not only gives her power because of her beauty, it also tells her who she is and how to feel and defines her. Her role in society as a model is to be males' fantasy, and not only in a sexual way but also because it is the male photographer (male society) that tells her how to feel. This quote shows how it is the male patriarchy, which defines the female. She is both a blank slate for the creator (photographer) and the model of how women should be: ready to take orders from the dominant discourse.

Furthermore, looking at what it is the photographer is telling her to feel, the extent to which this logocentric society is trying to control her is seen. The photographer is telling her to give him lust. Women are set up as lustful/sexual objects of male fantasy. They are something the male desires and delights in as a possession. Then the photographer wants malice. Malice can be seen as the photographer setting up women as dangerous, the femme fatal. The photographer wants her to participate in the evil job of creating false needs for consumers, or it can be seen as the stereotypical construct of women as evil castrators of men. This idea of malice comes after 
the command for lust, which sets up the traditional beliefs of women, lust, and evil which tells society that sex is bad; that Eve tempted Adam; that Helen launched a thousand ships to go to war, and that malice has followed women throughout history because of their "lustfulness nature."

The manner in which Shannon's job defines her through commands yelled out by male photographers, leads to Shannon's desire for "detached existential ennui." Shannon is tired of the limited choices given to her by society. She seems to be saying she is bored with the existential idea of defining herself. If the existential ideal is that one takes responsibility for one's actions, and Shannon is bored with that idea, it shows how she has lost her sense of self. As she says "...unless the meter is running and some photographer is yelling" then she cannot come up with the proper emotions to feel about the situation, which leaves her free of the responsibility of making her own choices. Throughout the novel Shannon conjures up the "famous fashion photographer" to remind herself to feel something about the situation.

It also underscores how others, who in turn, are motivated and defined by what they think society wants, define her fundamental being. In a patriarchal society the man will make the decisions for her (including the decision of how she should feel). Therefore, she should be detached from any feeling of creating her own meaning (the existential ideal of creating one's own meaning through the choices one makes) and the idea should be ennui-in the origin of the word, which is 'it is hateful to me.' The idea of existentialism and of existence, itself, should be detached and hateful to her, and this is how the photographer is telling her she should feel, or it is (in its intertextuality) how she feels about her life. He gives her power in the form of money and the power she has as a beautiful woman, but he takes it away by telling her how to feel.

Finally, there is the inter-textual quote; the merging of directions from the photographer and Shannon telling herself to use 'intellectualism as a coping mechanism.' Whether it is Shannon telling herself to use this method or the photographer is of little importance at this point 
because words only get meaning through this intertextual play. Everything Shannon thinks is determined by the male dominated world around her. And what this is telling her is to use intellectualism to cope with society; that is to say, she is to use the idea that reason (reason is a privileged term that goes along with males) is the ultimate principle of reality, as her way to cope. But Shannon is now realizing that her whole life has been determined/defined by the male dominated society she is in and that has told her how to feel and act. This is why she decided to rid herself of her beauty, which was her only means of power and was given to her by the patriarchal society controlling her. Now she will start to break free from these ideals with the help of Brandy by creating her own narrative of her life.

Shannon decides to break free from societal constraints by disfiguring her pretty face; this is her protest against the power she has been given by society, and this is a way for her to redefine herself on her own terms ${ }^{22}$. Shannon tells us that she was addicted to the attention her beauty brought her, and then she describes how her beauty made society treat her as only that pretty face, and she describes how she reacted to that beauty and attention:

I was tired of staying a lower life form just because of my looks. Trading on them. Cheating. Never getting anything real accomplished, but getting the attention and recognition anyway. Trapped in a beauty ghetto is how I felt. Stereotyped. Robbed of my motivation.

...This is the biggest mistake I could think would save me. I wanted to give up the idea I had any control. Shake things up. To be saved by chaos. To see if I could cope, I wanted to force myself to grow again. To explode my comfort zone (Palahniuk IM 286).

\footnotetext{
${ }^{22}$ That is, as much as one can say that these terms are hers since she is always caught up and bound up within society and only has the vocabulary given to her by that society.
} 
In the hospital, she comes to realize just how much language is defining her, and without language, she is left without an identity. Throughout the story Shannon relates how the constant changing of discourse with Brandy has left them without a language, "I have no native tongue" (Ibid. 27). She refers to the words people use and lets her audience know that "Those were her words" (Ibid. 33), or "Those were all her words..." (35), "There's not one word from my love cargo in the trunk" (170) twenty-six times throughout the novel. In relation to being preoccupied with other peoples' words, Shannon refers to something (mostly herself) as invisible fourteen times, which stems from her not being able to speak. Without a voice, Shannon is left invisible, and she is unseen by a society that privileges the spoken word over the "...pen and paper so [she] could communicate" (Ibid. 33). Derrida, in Of Grammatology, outlines how society has always privileged the spoken word because the spoken word is "present" whereas the written word is, to use a phrase Palahniuk is fond of, "a copy of a copy," and thus always one step removed from the "real thing" found in $\operatorname{speech}^{23}$. Shannon, without a voice, is overlooked by a society in which the spoken word is important. This is illustrated in the miscommunication Shannon faces when she does try to talk. Without a voice, and with only a pen and paper to communicate, any speech act that Shannon attempts is misunderstood, so now her pen and pad are not the only thing that is a copy of a copy but her voice becomes a mere copy of what is termed communication by society:

I say, "De foil iowa fog geoff."

And Evie says, "You're welcome."

Sister Katherine says, "But you just ate lunch."

It's clear enough, nobody understands me here (Palahniuk 53).

\footnotetext{
${ }^{23}$ For example, Derrida informs the reader how speech is seen as natural by saying, "... speech being natural or at least the natural expression of thought, the most natural from of institution or convention for signifying thought, writing is added to it, is adjoined, as an image or representation. In that sense, not natural. It diverts the immediate presence of thought to speech into representation and the imagination. This recourse is not only 'bizarre,' but dangerous" (Of Grammatology 144).
} 
Shannon has lost the two main components that define her: her beauty and her language, and as an invisible woman she can, or rather, she hopes to start over by defining herself without her beauty to get in the way. She also realizes (with the help of Brandy) that identity is not a fixed, static thing. In other words, Shannon has realized that she need not be defined solely on her beauty but rather on the "story" her body tells society. Without language, Shannon is unable to express her identity in any other way than through the story of her face ${ }^{24}$. What Shannon says about her situation reveals how much Shannon is beginning to realize that there is no "fixed" really real thing about identity:

Not that anybody in this big drama is a real alive person, either. You can trace everything about Evie Cotrell's look back to some television commercial for an organic shampoo... The only other character here is Brandy Alexander... The thing about being cloned from all those shampoo commercials, well that goes for me and Brandy Alexander, too. Shotgunning anybody in this room would be the moral equivalent of killing a car... Probably that goes for killing anybody in the world (Palahniuk IM 12).

Shannon is expressing what Solomon says about postmodern society:

In the postmodern worldview, there is no such thing as an essential 'me,' no centering self-identity, no inborn character. There are only roles, images we take up in imitation of other images (Solomon 227).

What Shannon is expressing here is a moment of her identity crises, and her flirtation with nihilism. If there is no essential self, then there is no morality that says one cannot kill another, "...the moral equivalent of killing a car." There is no essential "me." There is no "thing" that is graspable about a self; there is no self-same identity that would, in Shannon's mind at this

\footnotetext{
${ }^{24}$ As will be discussed later, Shannon says that after her accident, she just wanted someone to ask her what happened to her face and this is because without language or beauty, this 'accident' is what defines her identity now.
} 
point, make it morally wrong to kill. And the reason that there is no essential self is because one's being is bound up in language, and without language there is no consciousness; furthermore, since the idea of self (identity) is within language, the self can never be fully present to one's very own self. The self/identity is always-already, as the Eagleton quote earlier illustrated, going to never be fully present ${ }^{25}$, so without language, Shannon feels especially invisible and bitter. At this point, Shannon turns towards a nihilistic attitude, in which she feels that there are no moral rules that say that killing is wrong ${ }^{26}$. She does, however, end up believing in an essential narrative by which to live her life, and that narrative, as will be discussed later, is love.

Shannon has started to break away from the logocentricism of society, a society that says you have to 'find yourself,' that you are lucky to have beauty, that you are defined through speech, and that tells children to learn from your mistakes while trying not to make too many of them, by taking a gun to her face. Shannon is caught in a postmodern society because of her "beauty ghetto" as she puts it. Shannon is a victim of society from childhood. As Denzin states:

Childhood and youth are the doors one must open and pass through, on the way to becoming a member of this postmodern world. One must be motivated to open this door into the postmodern. Hence needs and desires, specific to children and youth, males and females, must be created. They must become desiring subjects who desire the needs and gratifications that the culture holds out to them (15).

\footnotetext{
${ }^{25}$ Furthermore, since Shannon is caught up in a Western Metaphysical world that privileges presence over absence, the absence of her speech leaves her unable to communicate and unable to identify any self or identity whatsoever. Even if it is an identity that is not fully present, fixed, and static.

${ }^{26}$ That is not to say that it is not wrong to kill an other. Heidegger says that we are with-others. Derrida, influenced by Levinas, will say how there is an a priori responsibility to the face of the other. Furthermore, Shannon will eventually accept love as an ineffable, a priori telos. But first she falls into the nihilism seen here, believing that since there is no essential self, that it means there is no moral responsibility. What she will come to understand is that while there is no fully present, meta-narrative, absolute moral code, there is the responsibility to the other, and Shannon will give her identity up to Brandy in a truly altruistic manner (not wanting anything in return) in the name of love.
} 
Shannon decides to mutilate her face to break free from the desires which society has made her crave. She has opened the door to the postmodern, but now she is trying to go back through the door and lock it behind her. Shannon's beauty and youth made her both a consumer of the constructed needs society held out for her and made her into the producer of constructed desires and needs. By mutilating her face, she has less material constructed needs and has escaped (as much as is possible) being a conduit of constructed needs.

Shannon (with the help of Brandy) has realized that the only way to try to get outside of the 'trap' is by changing the discourse. The only way she can see to try and escape is to make the biggest mistake she can possibly think of because 'anything we want, we're trained to want.' While she will always be in the 'trap' of society, she will try to subvert that trap as much as she can by trying to do the opposite of what is expected of her. Rather than want to change into something that she might want, Shannon (and all the characters) try to do the opposite of what they want. They will not try to be 'saved,' or try to 'find' themselves as traditional narratives encourage; instead, they will challenge every discourse that has been given them by society, and they will challenge all the definitions and binaries that society has put into place. In the end, this is all a story-life is all one big discourse, one big story, and Shannon realizes that:

What $[$ she] needs is a new story $[\ldots]$

What Brandy's been doing for me.

What I need to learn to do for myself. To write my own story.

Let my brother be Shannon Mcfarland.

I don't need that kind of attention. Not anymore (Ibid. 296).

The discourse that dominates society is traditionally a male, patriarchal society in which stories are used to indoctrinate the members of society. Shannon, though, wants to break away from this hierarchy when she recounts the story of another beauty with power: 
Mirror, mirror on the wall, who's the fairest one of all? The evil queen was stupid to play Snow White's game. There is an age where a woman has to move on to another kind of power. Money, for example. Or a gun (Palahniuk IM 31).

Fairy tales are a way to indoctrinate children into society and teach moral responsibility while also teaching little girls to want beauty and a 'happily ever after.' Shannon feels she was stupid to play that game - to let society define her-and now she will find power another way as she says women have to move on to another kind of power besides beauty.

Shannon realizes that she has to break out of the constraints of a patriarchal society, and she destroys her looks in search of another power. She will no longer play 'Snow White's game,' and she will no longer care to be the fairest one of all. Rather than beauty, the power given to her by the patriarchy, she will use the same power apparatus that men hold in esteem: 'money, for example. Or a gun.' With this passage, she also starts to realize how life is a "story," just a text to be interpreted. This is known because she refers to "Snow White" which is a narrative, and just how Snow White is interpreted, Shannon realizes her life is interpreted. Snow White is a character that Shannon relates to because Snow Whites power was in her beauty, so what would Snow White do without her pretty face and fair skin? Shannon is trying to find the answer to that question.

When Shannon recalls memories about her life before her "accident" she says, "It was stupid, my not knowing what was happening all along" (Ibid. 46). The emphasis here is on "not" and the past-tense verbs. Now, though, Shannon is realizing that language, the way she knew it, is a social construction, and she will, with the help of Brandy, begin to rebel against it until she reaches the end of this story, which is a place where she gives up her identity (her constructed by the dominant discourse identity) up and over to her brother/sister: Shane/Brandy, who will now become Shannon since Shannon gave him/her Shannon's identity. Shannon will give up her identity at the end of the story because she realizes that giving up her identity is the only way to 
break out of society's narrative. Although Shannon will still be stuck in the trap, she can change the trap by changing the facticity of her situation. Without her beauty society will define her in a different way; without her job as a beautiful model, society will look at her different; without a past for society to judge her on, Shannon is (somewhat) free of the restricting societal trap.

Shannon is left in a world of simulation and simulacra, a world of appearances:

Me, I just want Shane to be happy. I'm tired of being me, hateful me.

Give me release.

I'm tired of this world of appearances [...] Families that only look happy.

Give me deliverance.

From what only looks like generosity. What only looks like love.

Flash.

I don't want to be me anymore. I want to be happy, and I want Brandy Alexander back (Palahniuk IM 291).

Shannon wants to break free from that world of everything is fake, but there is no escape from that world as Brandy says:

It's because we're so trapped in our culture, in the being of being human on this planet with the brains we have, and the same two arms and two legs as everybody has. We're so trapped that any way we could imagine to escape would be just another part of the trap. Anything we want, we're trained to want (Ibid. 259).

Shannon finds that the story she wants to write for herself is one of love because love can be expressed in a transcendent way through poetic language. Derrida articulates that all responsible bearing witness is done in poetic language ${ }^{27}$, and if this is true, then it can be said that

\footnotetext{
${ }^{27}$ The Poetics and Politics of Witnessing. Sovereignties in Question: the Poetics of Paul Celan. Trans. \& Ed. Thomas Dutoit and Outi Passanen. Fordham University Pres. New York, NY. 2005. Poetic language, according to Derrida, is one that is non-representational. Rather than say I love you directly, Shannon tells the story (bears witness) for Brandy and herself, but tells the reader from the beginning that this is a story, and that there will be the feeling of missing something. Part of that feeling of
} 
the expressions of love occur in poetic language as well. If there is one motif that is present throughout the story, it is one of love $\mathrm{e}^{28}$. Shannon, while rejecting any metanarrative ${ }^{29}$, does embraces one narrative without change, "Completely and totally, permanently and without hope, forever and ever I love Brandy Alexander. And that's enough" (Ibid. 297). As such, we can conclude that in society she evinces the characteristics of an "undecidables." She is both within society (because that is the only place she can be in), but she is invisible in that society. She is defined by the story imposed on her by society, but she is also 'writing' her own story. She is a model, but she is ugly. She is the term that undermines binary opposition without invoking a third term; she is both either/or, as Derrida terms it: undecidables.

Shannon, while trapped in the system, has realized that the story changes and that she can have some control over the nature of the discourse; for instance, as she says of mutilating her face, "Because I'm tired of hating and preening and telling myself old stories that were never true

missing something arises out of the poetic language that does not claim to directly represent actual events. In the same manner that Derrida describes the witness as someone saying "I am telling you the truth; I am telling you what I think" (87), so to is Shannon telling her brother, Brandy, "I love you," and furthermore, Shannon is giving herself - her identity - over to her brother. Both the "love" and the "identity" here are working under the same conditions of possibility, which is that they are non-static, non-fixed, but rather always-already becoming. Identity cannot be fixed, because if identity is fixed, and one can say, "I love" this or that trait or this or that person specifically, then that love is one doomed to falter when that "thing" or person changes. Rather the poetic language that expresses love is one that works under this non-static condition, which mean there is something transcendent about "love"-which means that love and identity here become something that cannot be put into words, but still somehow there, in a non-traditional, metaphysical way.

${ }^{28}$ Granted, it is given that 'love' here is a more open term. But there are the love stories between Shane and Manus; Manus and Shannon; Shannon and Brandy/Shane; and Evie with herself. This is done, I believe to show how our conceptions of love are constructed ones that need to be looked at more closely. This is just another way that the characters play with definitions given by society and try to change the discourse of love. Therefore, "love" here is un-definable in words, but rather, as the above footnote mentions, love is something transcendent, un-fixable and thus outside of language.

${ }^{29}$ The metanarrative is suspicious to many in a postmodern world. Palahniuk, at a talk he gave in Coral Gables Florida, said how he liked the breakdown of metanarratives that give us unequivocal answers because this opens up the opportunity for one to make one's own narrative for one's life and search out one's own answers insofar as this is possible. This goes back to Lyotard who says the postmodern age is defined by an "incredulity towards metanarratives," (xxiv) which leads to a breakdown in legitimization of the narratives in place. Which narratives is society to believe in? The answer for Palahniuk seems to be one that involves love, as he says in the interview quoted earlier, all his books are about bringing people back into community. And just as is seen here with Shannon who wants to define herself, the implication is that she cannot have an identity in a vacuum, outside of society. 
in the first place. I'm tired of always being me, me, me first. Mirror, mirror on the wall" (Ibid. 295). She now understands how all the fairy-tale stories of 'Snow White' are all made up in order to indoctrinate her into society, and so she chooses to live another story and to give the gift of a new story to her brother/sister by giving up her identity to him/her. Now free of any identity ${ }^{30}$, she will be able to become whatever she wants to become just as Brandy has taught her ${ }^{31}$.

All this is possible with the help of Brandy who, in a sense, plays god and gives meaning to the other characters. Brandy does so only to show how meaning is acquired through context and perspective.

\footnotetext{
${ }^{30}$ That is to say, free of a specific identity. As a woman with a certain personality, she still has some sort of identity imposed on her by society, but how she uses the way society looks at her will now be determined by her as she is no longer duped by the constraints of society.

${ }^{31}$ The other thing to notice is that Shannon is able to give up her identity, and in a sense move on and also love again, only after she knows that somebody knows her story. Up until then there are a number of times in which she conveys that, "All I want is somebody to ask me what happened. Then, I'll get on with my life" (Palahniuk IM 45). It is only after she tells her story to Brandy, and Brandy helps her realize that it is just a story that she is able to move on and fall in love. In the hospital, Shannon says, "... no way could I fall in love... Settle for less" (Ibid. 48). At the end of the novel we find that she is able to love her brother/sister and move on.
} 


\section{Chapter Two: Brandy Alexander}

Brandy Alexander looks up at the last possible instant and winks. God should be able to wink that good. Like somebody taking your picture. Give me joy. Give me fun. Give me love (Palahniuk IM 47).

While the story is told from the perspective of Shannon McFarland, it can easily be argued that this is Shane's/Brandy's ${ }^{32}$ story. Brandy creates a new discourse for the other characters and gives them meaning, but the meaning she gives to the other characters is not a static one; it is a meaning given only to show them that they can change that meaning (and therefore change the story of their lives) whenever they want. Brandy defies any kind of totalization, stereotype, or label. For instance, the typical jock in high school would not normally be thought of as gay, and yet Shane is a basketball star. Moreover, Shane, a presumably goodlooking young man, has decided to scar his own face before he can be defined by his looks, and unlike the other characters that have, more or less, a definition of their identity by the work they do, ${ }^{33}$ Brandy has no job and thus avoids being classified and identified by his job. Brandy's search for uncharted waters of identity is through the waters of the biggest mistake she can think of to make:

"I'm only doing this [getting a sex change] because it's just the biggest mistake I can think to make, it's stupid and destructive, and anybody you ask will tell you I'm wrong. That's why I have to go through with it."

\footnotetext{
${ }^{32}$ The name Brandy and Shane will be used interchangeably as they are the same person, and I feel sticking to one name throughout will go against the non-static identity that Shane/Brandy is hoping to achieve.

${ }^{33}$ As mentioned earlier, Shannon is defined by her job as a fashion model and the photographer yelling at her how to feel. Later Manus will be obsessed with proving himself through his job as a special vice operative. As an under cover "police" operative, he identifies himself by how well he can attract older gay men.
} 
Brandy says, "Don't you see? Because we're so trained to do life the right way. To not make mistakes." Brandy says, "I figure the bigger the mistakes looks, the better chance I'll have to break our and live a real life."

Like Cristopher Columbus sailing towards disaster at the edge of the world.

Like Flemming and his bread mold (Palahniuk IM 258).

It seems that from his early teen years, Shane has been fighting against societal labels, and as is revealed in this passage, Brandy will even oppose the most 'fixed' labels of gender construction. In realizing that his identity is constructed by society, Shane realizes that her identity is just the story that society has given her/him. Consequently, Brandy feels that the only way to change her story is to change her body, and this would be the biggest mistake she can think of to make because she does not want to be a woman. It is precisely because Shane does not want to be a woman that he decides to have a sexual reassignment surgery. This is another way that Brandy challenges the popular discourse, his/her decision has to be purposeless and have this transgressive character (Brandy will get her meaning from this meaninglessness act) in order to make us rethink our whole understanding of meaning.

By having a sex change, Shane will make his body, the one thing that is Shane's that society has little influence over, his story. Shane compares his sex change to a person who climbs a mountain: that person has no real reason to climb the mountain but will be changed by that experience and, in the end, "... all she has to show for it is her story" (Ibid. 259). Brandy has no real reason to get the sex change, but by doing so she is like the mountain climber who wants to climb the mountain just because it is there, and by doing so she will make her entire body her story. This is her most radical rebellion against societal constraints.

Brandy seems to have realized early on that she wanted to be outside of society's labels. At the age of 15, Shane had his hair spray "accident," which is later revealed to be self inflicted, 
and then by the age of 16 , Shane is diagnosed with gonorrhea and is kicked out of the house. Before that, Shane, like everyone else, is defined by society, and even within his situation, his parents have a certain image of him (a way they define him), which is why they react by kicking him out when their definitions of him are altered. The clearest example of Shane's society defining him before and after Shane takes over his own definitions is the way Shannon talks about him, "The voted best at everything. The basketball king until he was sixteen and his test for strep throat came back as gonorrhea, I only know I hated him" (Palahniuk IM 96). Shane was defined as being the star of the basketball team and a bastion for heterosexual behavior in the eyes of his parents and society. His parents are completely perplexed and extremely upset by Shane's alternative lifestyle:

"It's not strep throat you've got, mister, and we'd like to know what you've been up to."

"Drugs," my mom said, "we could deal with."

Shane never said a word. His face still shiny and creased with scars.

"Teenage pregnancy," my mom said, "we could deal with."

Not one word.

"Doctor Peterson," she said. "He said there's just about only one way you could get the disease the way you have it, but I told him, no, not out child, not you, Shane."

My father said, "We called Coach Lublow, and he said you dropped basketball two months ago."

"[...]Tonight," my father said. "We want you out of here."

Our father. (Palahniuk IM 148-149).

This passage illustrates how the parents can accept most any transgression of moral norms except homosexuality. Society has accepted that teenage boys will experiment with sex 
(the consequence would be teenage pregnancy), and likewise that a teenager might fall into drugs, but the news of their basketball king dropping sports to go engage in homosexual acts is too much for Shane's parents to take. This passage also points out how Shane has further violated socially imposed definitions (the first resistance was by scarring his face) by quitting the basketball team, a normally accepted heterosexual and healthy activity for a young boy to do, and he has, of course, transgressed societal norms by simply being homosexual. In addition, there is the intertextual use of 'our father' showing how it is the father, the male, patriarchal, dominant, head of the household who decrees upon Shane his punishment. The father thinks that Shane, being gay, will ruin the McFarland family and the family's image. It is the image, after all, that is important; it is the image that is the story that society sees and accepts or rejects. It is also a reference to the Lord's Prayer which praises God's will and ask for forgiveness against one's own transgressions and that of others: "Sorry Mom. Sorry God."

With the family rejecting Shane's story, he leaves to start his own story. Brandy's story will start with Shane's death:

Jump to one night, somebody calling from a pay phone to ask my folks, were they the parents of Shane McFarland? My parents saying, maybe. The caller won't say where, but he says Shane is dead.

A voice behind the caller saying, tell them Miss Shane hated their hateful guts and her last words were: this isn't over yet, not by a long shot. Then somebody laughing (Ibid. 151).

Now that Shane is dead, he becomes Miss Brandy Alexander, and Brandy wants to challenge every discourse ever imposed on her by society and completely break free from totalizing labels and discourse. Brandy challenges the discourse by constantly changing herself and her story in order to try to avoid any fixed definitions. She will also (this isn't over yet, not by a long shot) find her sister, Shannon, and teach Shannon that the only way to break free of 
socially imposed definitions is by her method of "...the Brandy Alexander Witness Reincarnation Project" (Ibid. 187). Just as the Rhea sisters took Brandy and adopted her and changed who she is, now Brandy helps others break out of their socially imposed roles and become new people. Brandy's task is to give her "Project" members constantly changing roles and to have them realize that their past and present is just a story, and that they have to constantly look into the future for who they will become-which will change. This constantly changing story that Brandy gives to the people around her is like Heidegger's Dasein, which is constantly being thrown forward ahead of itself, thus, never static or fixed. This is not to say that this is the way that Dasein is. The always-already thrownness of Dasein is a radically prior constitutive element of being rather than a decision that Dasein makes. This is to say, rather, that there are ways to be in the world that Brandy is embracing.

Dasein is not a definitive thing that can be observed, and it is not fixed or static, just like the constantly changing stories Brandy tells through her actions, words, and deeds are not fixedand this is a way to show how identity (words, actions, etc) is not fixed either.

Dasein is rather the possibility of many things, in other words, potentiality. Brandy is trying to convey to the other characters that their being has to embrace this potentiality, and the way Brandy expresses this potentiality is in the way she teaches the others ways to live (ways to be). Brandy shows the others how to constantly be be-coming, by constantly changing identity and the way she is in the world. Brandy embraces this fluctuation of identity and tries to teach it to the other characters. And while no one cannot decide to be born in a different culture or to different parents (what Heidegger refers to as being "thrown" into the world or what other philosophers call facticity), one can decide what they are going to do with the situation within which they are thrown. Brandy takes this existential idea of taking control of the situation one is thrown further because while most people feel they have no control over what gender they are born and accept their gender as part of the thrownness of identity, Brandy will change that part of the narrative of 
his life. While most people interpret throwness as the difference between not whether or not to be but rather a question of how to be in the world, and therefore, a question of potentiality in the world, Brandy will explode the potentiality to include not only what she does and how she is in the world, but also what she is in terms of gender.

Brandy challenges her throwness, facticity ${ }^{34}$, her parents definition, her school's definition (certainly her basketball coach's definition), and once free of these constraints she challenges the more general conception of society defining him by changing her gender. Brandy believes that everything one could want, they are trained to want it, so for her, the only way to break free from that (or at least try and break free from that) is to search out and do all the things that she wants least; in this case, that is a sex change. If part of the structure of Dasein is potentiality, a sex change explodes that potentiality by adding the option of exploring the future as male or female. As Judith Butler notes, gender fixes one's potentiality and regulates a person into playing certain roles:

...[T] he notion that gender is constructed suggests a certain determinism of gender meanings inscribed on anatomically differentiated bodies, where those bodies are understood as passive recipients of an inexorable cultural law. When the relevant "culture" that "constructs" gender is understood in terms of such a law or set of laws, then it seems that gender is as determined and fixed as it was under the biology-is-destiny formulation. In such a case, not biology, but culture, becomes destiny (Butler 11).

\footnotetext{
${ }^{34}$ Thrownness and facticity are both terms that refer to the "concrete" fact of life (the inescapably phenomenological context of one's being); for instance, where one is born, who one's parents are, and usually one would assume that a component of that facticity is one's sexual assignment: male or female. But Brandy will challenge these conceptions. If society does not know the original story of Brandy's beginning, then she can, in a sense, change her facticity.
} 
Brandy will let neither biology nor culture determine who she is or her potentiality. She understands that sex and gender are not universally fixed concepts but rather, as Butler points out, constructs of society. Brandy does not want to be totalized; as she says:

I'm not straight, and I'm not gay...I'm not bisexual. I want out of the labels. I don't want my whole life crammed into a single word. A story. I want to find something else, unknowable, some place to be that's not on the map. A real adventure (Palahniuk IM 260).

It is here that we see Brandy's motivation for wanting to constantly change the story. She does not want her "life crammed into a single word" because that would lead to her only having one story (A story) when the real adventure lies in constantly changing the story. She realizes that part of her identity (her story) is sexual orientation, so she opts to not have a fixed one. She is trying to get outside of society's definitions to find something "unknowable" while at the same time realizing that there can be nothing that is "unknowable." Anything she thinks up will then become knowable, and further is always-already inscribed within a language that is constitutive of our understanding insofar as that understanding occurs in the terms in which we can think in the first place, which are themselves presented to us in language; thus again, "We're so trapped that any way we could imagine to escape would be just another part of the trap" (Ibid. 258). The problem for her is that there is no place "to be" outside the map because we are inevitably beingsin-the-world. The only way for Brandy to know anything is bound up with her facticity. The phenomenological facts of existence (our experience of the world from the time we are born, our place in the world, all the "facts" of where and when we are) are also fundamental of our understanding in an always-already fashion. All she can do is change the discourse in order to have another story to tell; furthermore, she will teach others to constantly change their discourse, 
for if she cannot break out of society ${ }^{35}$, then she will keep society guessing. This is seen the second time that Shannon sees Brandy in the hospital, "'If you can believe it,' the nurse says, 'that one is someone different every week"' (Ibid. 47). Brandy is fulfilling her potentiality by constantly changing that potentiality and be teaching others to do the same.

Ultimately, Brandy will fulfill the potentiality of her being by taking over one of the oldest and grandest metanarratives-she will become God. Brandy will hold the direct line of meaning from her to the outside world, but only to show the other characters that there can be no grand-meta-narrative ${ }^{36}$. Brandy will inevitably subvert the very notion of a "direct line" of meaning, which is akin to full intelligibility. It can be said that Brandy is playing the language game of society in order to try to break the social bond imposed on her by society. Lyotard describes this social bond and addresses how:

...language games are the minimum relation required for society to exist: even before he is born, if only by virtue of the name he is given, the human child is already positioned as the referent in the story recounted by those around him, in relation to which he will inevitably chart his course (15).

Lyotard further explains how the language game goal is not to win at the expense of an adversary but rather, "Great joy is had in the endless invention of turns of phrase, of words and

${ }^{35}$ Part of not being able to break out of society comes from Heidegger's idea of being-in. Opposed to the Cartesian cogito, which separates a consciousness from the outside world, an I that is separate from the world, Heidegger's in lets us know that Being is always-already in the world. It cannot stand outside or against the world, separate from it but is always in. This idea is also seen throughout Derrida's work, who point out the trouble with exploring the question of Being when one is being, or more popularly in terms of Derrida, the trouble with exploring the trouble with language but having to use that language. Brandy here wants to question society, but is always already within society.

${ }^{36}$ There is a running theme throughout Palahniuk's novels about Santa Clause, the Easter Bunny, and the Tooth fairy as children's training wheels for God: "'Santa Clause is just a story,' says Manus. 'He's just the opening band to God. There is no Santa Clause"” (Palahniuk IM 82); Also, “... Beginning with Santa Clause as a cognitive exercise, a child is encouraged to share the same idea of reality as his peers. Even if that reality is patently invented and ludicrous, belief is encouraged with gifts that support the common cultural lies" (Palahniuk An Oral Biography of Buster Casey: Rant 130). It seems that these childhood stories are what set some of his characters thinking about what else is a construct handed down by society in order to control the population. From this point, Palahniuk's characters seem to try to subvert societal meanings, constructions, discourse, and control in the unusual ways that they do. 
meanings, the process behind the evolution of language on the level of parole" (10), but what Brandy is doing is fighting a war with adversaries (society) and recruiting soldiers (the other characters). While Lyotard acknowledges that institutions dictate these games, and while he did foresee objections ${ }^{37}$, he claims that, "The war is not without rules" (17). It seems he did not take into account someone like Brandy, who-if the game is not without rules-is trying to change the rules and create a new game. But this is more than just changing the rules, something Lyotard acknowledges would happen, rather Brandy wants to create a whole new game by subverting supposedly fixed structures like gender, physical appearance, and socially accepted ways to make money.

Brandy becomes one of the institutions of society; also, she becomes a grand narrative, like Manus Kelly saying Santa Clause is the training wheels for God, Brandy becomes the training wheels for the other characters in order that they learn that they cannot get their meaning from God. She does this by first becoming God. As Manus says, "The Princess B. A. is God" (Palahniuk IM 83). The first time Shannon sees Brandy, Brandy seems to just appear out of nowhere, and Shannon has an experience of Brandy, one in which Shannon feels that Brandy is "reality" and the rest of the world just virtual reality:

Brandy Alexander was just so there, glorious in a seated Princess Brandy Alexander pose, in an iridescent Vivienne Westwood cat suit changing colors with her every move.

Vogue on location.

The fashion photographer inside my head, yelling:

\footnotetext{
37 "The objection will be made, at least, that the weight of certain institutions imposes limits on the games, and thus restricts the inventiveness of the players in making their moves. But I think this can be taken into account without causing any particular difficulty.

In the ordinary use of discourse - for example, in a discussion between two friends - the interlocutors use any available ammunition, changing the game from one utterance to the next[...] but the rules allow and encourage the greatest possible flexibility of utterance" (Lyotard 17).
} 
Give me wonder, baby.

Flash.

Give me amazement.

Flash.

$[\ldots]$

Brandy Alexander and the way she looked turned the rest of the world into virtual reality. She changed colors from every new angle. She turned green with my one step. Red with my next. She turned silver and gold and then she was dropped behind us, gone (Palahniuk IM 43-44).

This passage shows how Brandy parallels God, the word made flesh, light, all of which signify "the Truth." Looking at most any Bible, in Genesis, one can see how God is "just so there, glorious" in a vast void, and then He starts to create the world, and the first thing God creates is light. Brandy, the first time that Shannon sees her, is in the speech therapist office, and the therapist is teaching Brandy how to sound like a girl. The first thing Shannon sees is how important it is to have speech in order to be seen. One needs light in order to be seen, and one can see how throughout history the "word," speech, and light have all been interrelated (along with logos and truth), so that one can infer that there is no light without the "word"," no truth without light, and no word without speech, and furthermore, the person who has experienced the truth or the light of God is left in wonder and amazement. As Derrida says when he is exploring phonocentrism as part of the history of logocentrism and presence, and presence as sensible and intelligible thus debasing writing as a mere supplement, these ideas have been appropriated by Christianity and consequently Western thought in general:

\footnotetext{
38 "In the beginning was the Word, and the Word was with God, and the Word was God. He was the beginning with God. All things came to be through him, and without him nothing came to be. What came to be through him was life, and this life was the light of the human race; the light shines in the darkness, and the darkness has not overcome it" (John 1, 1-5).
} 
But to these metaphysico-theological roots many other hidden sediments cling. The semiological or, more specifically, linguistic "science" cannot therefore hold on to the difference between signifier and signified-the very idea of the signwithout the difference between sensible and intelligible, certainly, but also not without retaining, more profoundly and more implicitly, and by the same token the reference to a signified able to "take place" in its intelligibility, before its "fall," before any expulsion into the exteriority of the sensible here below. As the face of pure intelligibility, it refers to an absolute logos to which it is immediately united, this absolute logos was an infinite creative subjectivity in medieval theology: the intelligible face of the sign remains turned towards the word and the face of God (Derrida Of Grammatology 13).

It is the face of God that gives signs there "transparent" intelligibility, so if for the apostle John, logos is light (the Word) and the truth, then for Shannon, Brandy is an ever changing, never static light, and if God is the Word (light), He is the really real and all else is virtual reality without his light. Brandy will become the word made flesh only to show the other characters how the world they know is virtual reality, a simulacrum. She will temporarily take the place of God and "the intelligible face of the sign" will be turned towards her. Brandy does this in order to indicate that she is an empty sign, and that God is just an empty sign. Brandy becomes God without God in order to show how God does not hold full presence and meaningful meaning. Brandy becomes like her actions, a model of meaningless meaning. .

Brandy will inverse the idea of the really real reality and be the representation of an empty sign - there is nothing behind her, "The queen supreme's voice and the shadow of L'Air du Temps are the invisible train behind everything that is the world of Brandy Alexander" (Palahniuk 26). Brandy's world is made up of vapors; in other words, her world is an invisible vapor that is made up by Brandy herself. Brandy is taking on the role of Jean Baudrillard's 
iconoclast who says, "...That ultimately there has never been any God; that only simulacra exist; indeed that God himself has only ever been his own simulacrum" (172). Brandy herself is her own simulacrum and everything behind her is just scented air. She does this to show the other characters the proper power of the images that surround them and define them. Again, she sounds like Baudrillard's iconoclast, “...Who are often accused of despising and denying images, were in fact the ones who accorded them their actual worth" (Ibid.). Again, this is because the meaning is in an absence of full signification. Brandy, too, accords images their proper worth, but again, it must be kept in mind that she holds the image in high regard because it is the image that can be changed easily. The image of her body is what she wants to change in order to make her body the story of her life. This is further seen when Brandy makes Rona Barrett her new God because Rona Barrett changed who she was through cosmetic surgery and changing her story. Miss Rona Barrett is Brandy's (God's) new word made flesh, and, "Miss Rona says the only way to find true happiness is to risk being completely cut open" (Palahniuk IM 86). The way to be completely cut open is to share her life story, and to make that story whatever she wants to make it. And like God creating the universe, Brandy will create the other characters and give them a story to start with in hopes that they all find their own story to create.

Just as one can see God as a potter using His hands to fashion man out of clay (Genesis 2. 7), "If you have to start with any one detail, it has to be Brandy's hands" (Palahniuk 23). Brandy gives the character's life meaning the way God and religion give people meaning. Brandy is actually better than God at giving the other character's meaning:

...Brandy Alexander looks up at the last possible instant and winks. God should be able to wink that good, Like somebody taking your picture, Give me joy. Give me fun. Give me love.

Flash. 
Angels in heaven should blow kisses the way Brandy Alexander does and lights up the rest of my week (Palahniuk $\underline{\mathrm{IM}} 47$ ).

Brandy brings Shannon the joy and fun that Sister Katherine (and presumably religion and God) cannot. Furthermore, Shannon gets her identity from the fashion photographer in her head telling her how to feel, here Brandy by simply looking at her gives Shannon a sense of meaning and identity, without yelling out commands and without words. When Shannon is at a low point in the hospital and wishes she could tell her story to someone, Brandy is, "The queen of everything good and kind..." and when Brandy ask Shannon what happened to her face:

Brandy's voice, I barely hear what she says. At that instant, I just adore Brandy so much. Everything about her feels as good as being beautiful and looking in a mirror. Brandy is my instant royal family. My only everything to live for (Ibid. 56-57).

If one thinks of what God means to meaning- $-\mathrm{He}$ is the origin and all meaning can be traced, in a direct line, back to him. In a sense, Brandy becomes that for these characters. Brandy uses her hands to give direct meaning, but it is a meaning that will change yet meaning nonetheless:

Brandy's hand draws a sight line through the air from her smile and big boobs to Alfa [Manus]. "May I introduce," Brandy says, "Signore Alfa Romeo, professional male consort to the princess Brandy Alexander."

The same way, Brandy's hand swings from her batting eyelashes and rich hair in an invisible sight line to me (Palahniuk IM 24).

These identities (Alfa Romero in this case) are identities that are given to the other characters by Brandy, and while these identities might be "fake," for that moment that the three 
characters are committing a swindle ${ }^{39}$, this is who they are because Brandy (God) has told them that this is who they are. It is interesting to notice how the other characters get different identities in Brandy's game but Brandy is still Brandy, and the reason for this is that Brandy is the alter ego, the real ego, the constructed simulacra-all this and none of this-so there is no need for Brandy to come up with another name for herself (being that Brandy's "real" self is Shane, she is already inhabiting another ego). Brandy's hands (or some reference to pointing directly at actual, really-real meaning, along with references to Brandy as God, or the characters' experience as religious) are referred to twenty-three times. ${ }^{40}$ Shannon even refers to the time before she met Brandy as, "B.B., before Brandy" (Ibid. 109). This is obviously a mock reference to B.C. for before Christ, another person who was sent to show people that they were interpreting the Word of God incorrectly and whose word became flesh.

While society is looking towards God for salvation and meaning, Shannon has found salvation and meaning in Brandy, or rather, Shannon has found the opposite of salvation and meaning: she has found a way to go against what society deems normal and appropriate, and she has done this because Brandy has listened to Shannon's story and teaches Shannon that identity, society's rules, and life are just a story. After Shannon can realize that her life is just a story, then she will be able to move on. As Brandy explains to Shannon:

You are going to tell me your story like you just did. Write it all down. Tell that story over and over. Tell me your sad-assed story all night... When you understand...that what you're telling is just a story, It isn't happening anymore,

\footnotetext{
${ }^{39}$ One of the subversions, and one of the reasons for creating these constantly changing identities, is in order to make money, the characters pretend to be rich house buyers, and when they go look at high end houses, Manus distracts the realtor while Brandy and Shannon raid the bathroom looking for prescription medication that the characters then sell at clubs at night. Even their manner of making money in society is a transgression from the norm.

${ }^{40}$ Pages: 23, 24, 25, 28, 29, 47, 56, 57, 58, 61, 64, 71, 83, 88, 109, 113, 186, 187, 215, 219, 240, 282, 297. This does not include the numerous times Brandy is referred to as "The Queen Supreme" as in the Supreme Being.
} 
When you realize that the story you're telling is just words, when you can just crumble it up and throw your past in the trashcan...then we'll figure out who you're going to be (Palahniuk $\underline{\mathrm{IM}} 61)$.

What Brandy wants Shannon to realize is that there is nothing outside of the text, even in biography and lived experience. The reason for this is not because Shannon's life does not exist, and it is not because her life is not of interest or importance to the reader, nor is it because the reader can never have access to her experience or her "real" existence. It is because the only way to interpret her life from the outside is through the text she writes of her life. And the only way for Shannon herself to interpret her life "from the inside" is through language. Once Shannon can realize that all society will see of her is this sad story of hers, then she can use it to her advantage in order to create whatever story she wishes to of her life. It is the word of Brandy that liberates the characters by preaching how:

Now hear the word of the Lord.

You're a product of our language... and how our laws are and how we believe our God wants us. Every bitty molecule about you has already been thought out by some million people before you (Palahniuk IM 219).

Here it can be seen how much Brandy has taken over for the final signified the Lord used to be. Shannon intermixes her thoughts of God with Brandy because Brandy has become such a God to her. Brandy ${ }^{41}$ wants Shannon to tear herself open and, in a sense, bear her soul the way a repentant sinner would before accepting God, "Come on, let's see those glistening, quivering

${ }^{41}$ Another way to look at Brandy is in comparison with Jesus Christ. Not to say that she is a Christ figure that is sacrificing herself for mankind, but in the sense that she becomes the word made flesh-the word of Rona Barrett, Brandy's God. This compares to Jesus preaching the Word of God, and Brandy preaching on the constant road trips. This interconnected chain also goes along with the postmodern convention of intertextuality, and with the idea that nothing is original (there is no origin), and there being no origin and nothing original so that you have to make your own story is the word of Rona, passed on through the word of Brandy, "Seth says, 'Praise God,' [...] And Seth says, 'Hallelujah!'” (Palahniuk IM 85). This is quite a purposeful response for someone driving a car listening to someone else talk. 
innards, Bubba Joan[Shannon]," Brandy Alexander, God and mother of us all, commands. 'Tell us a gross personal story" (Ibid 88).

It is through Brandy's constant preaching about how society constructs identity, and about how, "There isn't any real you in you" and how, "Nothing of you is all-the-way yours. All of you is inherited" (Ibid. 218), that Shannon will be able to take her past-the story of her pastand throw it away, and thus, create a new story. Shannon cannot objectively convey the story of her life (her biography) because she is within the story. Shannon is always already telling a story when she speaks or writes of her life, and as she speaks or writes the story of her life-that act (of speech and writing) become a part of her life. Brandy wants Shannon to realize that what she says of her 'sad-assed story' can be thrown away, and that every time she tells the story it will be reinterpreted by the listener or reader or even herself; therefore, they can come up with whatever story they want of their life.

With the word of Brandy, there is no guilt for actions since actions are the result of being trapped in society:

It helps to know you're not any more responsible for how you look than a car is... You're a product just as much. A product of a product of a product. The people who design care, they're products. Your parents are products. Their parents were products. Your teachers, products. The minister in your church, another product (Ibid. 217).

It is because of this chain of being and identity that any choice one can think of to make is just another part of the trap. Brandy's preaching makes her the perfect simulacra and simulation of a world in which religion still has meaning. Baudrillard discusses the simulation as, "...the generation by models of a real without origin or reality: a hyperreal" $(169)^{42}$. Brandy has become

42 "Brandy Alexander and the way she looked turned the rest of the world into virtual reality" (Palahniuk 44). 
the hyperreality of God. She is, through representation, a 'generation' of a God without any origin or reality of an actual God. She is also, as Shannon says of her, "All this sparkle that bends over besides my bed could be the trail-sized mock-up for the original night sky" (Palahniuk IM 113).

As a product of a product everything becomes hyperreal, "...The product of an irradiating synthesis of combinatory models in a hyperspace without atmosphere" (Baudrillard 170). Brandy is the product of her parents, religion, teachers, coach, and then of Rona Barrett, the Rhea sisters, and this is why she feels trapped in society's constraints and searches out for the most extreme ways to break free from wanting something that does not arise out of being a product of everything that was before her. Brandy realizes that everything that came before her was the story-the product -of society, and this is the message she teaches the other characters.

Brandy gets Shannon to realize that her story is constructed and the product of a product, but Brandy also gets Shannon to finally realize that the story is constantly changing whether she wants it to or not, so not only is the story of identity the results of a product of a product, it is also something that can be, to an extent, manipulated. Shannon, with the help of Brandy, realizes that being is, as Heidegger says, a constant thrown forward ahead of itself, when she says:

Fuck me. I'm so tired of being me. Me beautiful. Me ugly. Blonde. Brunette. A million fucking fashion makeovers that only leave me trapped being me.

Who I was before the accident is just a story now. Everything before now, before now, before now, is just a story I carry around, I guess that would apply to anybody in the world. What I need is a new story about who I am.

What I need to do is fuck up so bad I can't save myself (Palahniuk IM 224).

Brandy has let Shannon realize that Being is constantly ahead of itself, constantly thrown in the world ahead of itself in all its potentiality. Therefore, it is up to the characters to fulfill their 
potentiality at every second 'before now, before now.' They need to make up their own stories, but they know that it is a story that cannot be static or fixed. Brandy has changed the story so many times that, "There isn't one native tongue left among us" (Ibid. 84). Brandy has shattered the idea of there being any origin since she has realized that the world they all inhabit is just a product of a product or a hyperreal simulacra and simulation. Derrida is another opponent of the idea of an origin; talking about Levi-Straus's work, but applicable to any system claiming an origin, Derrida says:

There is no unity or absolute source of the myth. The focus or the source of the myth are always shadows and virtualities which are elusive, unactualizable, and nonexistent in the first place. Everything begins with structure, configuration, or relationship. The discourse on the acentric structure that myth itself is, cannot itself have an absolute subject or an absolute center (Writing and Difference 286).

Much like what Shannon and Brandy are saying about the myth of a true identity, a you in you, there is no source for this myth. It is all just shadows, and the idea that there is a you in you is just the way it has been structured to make society think that there is an origin and not just shadows, and the problem is that the origin cannot be traced back to the beginning since everything is just a copy of a copy. Brandy, then, teaches Shannon to not only come up with a story for her life, but to come up with an unknowable story:

A sphinx. A mystery. A blank. Unknown. Undefined. Unknowable. Indefinable. Those were all the words Brandy used to describe me in my veils. Not just a story that goes and then, and then, and then, and then until you die (Palahniuk IM 260).

In other words, by veiling the story (and Shannon's story is her face, just like Brandy's is her body), Shannon's story will not become one that goes "and then" but presumably one that is 
incessantly in motion - a story worthy of Dasein's constant always-already there-being. Also this story must be read the way Derrida suggests:

But a reading here should no longer be carried out as a simple table of concepts or words, as a static or statistical sort of punctuation. One must reconstitute a chain in motion, the effects of a network and the play of syntax (Derrida Dissemination 194).

This is why the story has to constantly change because the characters are reconstituting that chain in motion, and this more poignantly shows the effects of the network at play within the intertextual moments of the characters' lives. This was Saussure's idea of intertextuality, as stated earlier. These characters can only get meaning, or make meaning out of their lives, through the intertextual play of all of their lives. All of their lives, after all, are connected and mixed like words and sentences on a page. Furthermore, this constant changing of the story (so that here is "no native tongue left" among the characters) is done in order to not totalize the discourse they are creating. By having the story of their lives constantly moving and changing there is no-thing that is graspable or inherent in their story. Their story becomes a constant flux rather than a static and fixed "thing."

It is interesting to see how, while Brandy gives everyone their meaning in order to teach them that they can come up with their own stories for their life, in the end, she receives her identity from her sister. In return, Brandy teaches Shannon to love again, even without the photographer in her head telling her to do so:

Even when I'm not getting paid, I can give love and happiness and charm....Completely and totally, permanently and without hope of reward, just as an act of will, I will love somebody (Palahniuk $\underline{\mathrm{IM}} 295)$

Since Brandy looks so much like Shannon, (and Shannon has no face), Shannon will give her identity over to Brandy, and that is an identity that is on its way to becoming a famous fashion 
model. In this way, Brandy can subvert all notions of what it means to be female, beautiful, and a model. Moreover, as a woman, Brandy will be able to live out what she has been preaching to Shannon which is why Shannon wishes the best for her brother/sister:

Be famous. Be a big social experiment in getting what you don't want. Find value in what we've been taught is worthless, Find good in what the world says is evil. I'm giving you my life because I want the whole world to know you. I wish the whole world would embrace what it hates (Ibid. 294).

If Brandy can ascend the hierarchy of the modeling world, it will be a victory for Brandy's big social experiment because while society is starting to accept homosexuality, it has not embraced the idea of the berdache. Brandy will go from being the symbol/simulacra for God to being the symbol for everything that makes society feel uncomfortable. Furthermore, by becoming a successful transgender model she will subvert society's notions of needs and desires and wants. If it is Cindy Crawford and her sexuality that makes society want to buy Pepsi, then what statement will be made if society wants to buy Pepsi if Brandy and her sexuality is the spokes model selling her sexuality for the product.

Trapped in society, Brandy will not let society define her any longer and will come up with her own story for her life and teach the other characters to do the same. Brandy will teach the other characters to break out of hegemonic discourses and embrace their sex-change or mutilation to be outside of "normal" society. It is in this manner that Brandy will deconstructing the binary oppositions that society has set up in order to control Brandy and the other characters. Realizing that society has created the 'text' for her life, defined her, imprisoned and controlled her through a patriarchal discourse, she will invent her own narratives to live by and teach others to do the same. Just as the earlier quote states, these characters want out of 'labels.' They want to be able to find someplace that is 'unknowable' and that is 'not on the map,' but the problem arises in: how can you know something that is 'unknowable?' How can you find a place that is 
'not on the map?' For the characters, the only recourse is to come up with a constantly changing story to live. They might be stuck in language and the narrative society has imposed on them, but they will do their best to create a new narrative for their lives and come up with new ways in which to live their lives. 


\section{Chapter Three: Evelyn Cottrell}

Lost in her own little closed circuit. Licking her own butthole...(Palahniuk IM 75).

Evie's problem is that instead of family and society defining her in a strict and constraining way, her family ignores her and turns her into an objectified commodity, which leaves Evie unloved and undefined ${ }^{43}$. It seems that Evie's motivation for her shifting identity stems from this feeling of being ignored and unloved by her family, so she looks for attention by being a model and through the drama she creates in her life. All the reader is told about Evie's childhood is from her mother, "'Why, it plum broke our hearts the day Evan came to us, Sixteen years old, and he says "Mommy, Daddy, I want to be a girl"' (Palahniuk IM 268). Evie has been treated like a commodity ever since this moment of transgression, which leads one to infer that he/she was treated like a commodity even before the sex change. As Evie's mother goes on to say, "We paid for it...A tax deduction is a tax deduction," and then explains how Evie wanted to be a famous super model (Ibid. 269). The illustrates that the parents do not care one way or the other what their son/daughter does as long as they can write it off and save some money.

Evie constructs her own drama because she has had none growing up, which makes her feel unloved. Evie's family, rather than treat her as their child, treat her as a commodity. This attitude towards Brandy is seen in the way they treat the life changing gender operation as a tax write off. Rather than confront the issues that Evie is going through, the family throws money at Evie. Treated as a commodity, Evie is unable to feel "real," and she is left without validated emotions. Evie, without the love of her family, goes in search of love through her work. She not only constructs her own identity but also her own drama. This attitude leaves Evie feeling unloved

\footnotetext{
${ }^{43}$ Evie is undefined as a person because she is defined as a commodity. She becomes an abstract object traded on the stock market.
} 
and unwanted, and this is shown as Shannon describes watching herself and Evie on T.V. in an infomercial:

The camera stays on Evie, and what I can almost hear Evie saying is, Love me.

Love me, love me, love me, love me, love me, love me, love me, I'll be anybody you want me to be. Use me. Change me. I can be thin with big breast and big hair. Take me apart. Make me into anything, but just love me (Palahniuk $\underline{\mathrm{IM}} 266)^{44}$.

Feeling unloved, it seems that Evie thought she could get some attention and love if she became a famous super model, which led to her sex change. It also is apparent that she was abused in some manner when she was young although it is unclear whether she was emotionally or physically abused. When Evie and Shannon are play-acting life at the mall, the reader gets hints that Evie might have been emotionally abused, "It's so safe and peaceful, here [the mall]... Nothing very bad could ever happen to you here. Not like at school. Or at home" (Palahniuk IM 71). The way Evie specifically points out how bad things happed at home and at school leads one to think that she was teased by both family and schoolmates for getting a sex change (or for simply being feminine) and for wanting to fulfill such an odd dream (of becoming a female super-model). She goes on to explain:

It's not just my wanting to be a glamorous fashion model...It's when I think of my growing up, I'm so sad... When I was little, my parents wanted me to be a boy... I just never want to be that miserable again.

... 'Yeah,' I'd [Shannon] say. 'My parents abused me, too' (Ibid. 72).

\footnotetext{
${ }^{44}$ It is interesting to note here that Evie is saying "Take me apart", which is what Brandy says needs to be done. As was discussed earlier, Brandy's God (Rona Barrett) says that, "... The only way to find happiness is to risk being completely cut open" (Ibid. 86). Additionally, Evie is willing to be made into anything, which is what happens in the end when the reader finds out that everything that has gone on is all staged and planned out. At then end, the reader learns that Evie and Brandy have directed the seeming chaos that is happening, and they both play (act out) their part.
} 
Through these comments, and others made throughout the novel, it seems that Evie just likes the drama of play-acting more than she really felt any kind of physical or emotional abuse. And she likes the drama of play acting because Evie's family just throws money at her in hopes to keep her quiet and out of their way, and they have instituted her as an abstract commodity on the stock market so that the money that is given to her can be a tax write off:

Evie really is Evelyn Cottrell, Inc. No, really. She's traded publicly now. Everybody's favorite write-off. The Cottrells made a private stock offering in her career when Evie was twenty-one, and all the Cottrell relatives with their Texas land and oil money are heavily invested in Evie's being a model failure (Palahniuk 124).

Since Evie is seen as just shares to be bought and traded, she is left with a feeling of emptiness, which is what leads her to create her own story, again with the help of Brandy. Evie goes to the mall in order to feel like a real person because she can only feel like a real person if others are watching her. This stems from no one in her family validating her by listening to, and loving her ${ }^{45}$. Evie explains:

"It's too lonely at my real house," Evie would say. "And I hate how I don't feel real enough unless people are watching."

She says, "I don't hang around Brumbach's for privacy" (Palahniuk 69).

Without any attention being accorded to her, without being in the spotlight, Evie's identity is unclear, which is why she creates drama in her life in order to get attention. Evie goes on to explain how being at the mall in these constructed habitats is like an animal being at the zoo in recreated habitats, and she also compares the mall's display rooms as sound stages, so she will fill the stages with action and receive validation from the "audience"- the other shoppers who stop and watch the plot play out between Shannon and Evie.

\footnotetext{
${ }^{45}$ This is similar to how Shannon is neglected by her parents who do not listen to her.
} 
Evie, in making up and playing out her own constructed drama, goes against the typical postmodern identity of society. Denzin describes the typical postmodern person as:

...A restless voyeur, a person who sits and gazes (often mesmerized and bored) at the movie or TV screen. This is a looking culture, organized in terms of variety of gazes, or looks (tourist, investigatory-medical, social science, television, religious, political-artistic, photographic and so on: see Urry, 1990: 135) (Denzin 9).

To the contrary, Evie is not a restless voyeur; she is the director, writer, and star of her own life, and while, "The raw racial and sexual edges of contemporary life produce anxiety, alienation, madness, homelessness, resentment, and anhedonia (Lymann, 1990)" (Ibid.), Evie is able to counteract these feelings by being an active participant in the drama of her own life. Denzin goes on to explain how large groups of marginalized people have been unable to, "live out their ideological version of the American dream, or to experience personal happiness" (Ibid.), but Evie is able to experience happiness by subverting society's version of that American dream by making up her own version. At the end of the novel-after the big climatic scene is described by Shannon-the audience learns that what has transpired throughout the climax of the novel has been staged and planned out by Brandy and Evie in advance:

Brandy yells, "Evie!"

And Evie's burned-up head sticks back in through the front doorway. "Brandy, sugar," Evie says, "This all's been the best disaster you've ever pulled off!"

To me [Shannon], Evie runs up and kisses me with her nasty melted lipstick and says, "Shannon, I just can't thank you enough for spicing up my boring old home life." 
"Miss Evie," Brandy says, "you can act like anything, but, girl, you totally missed shooting the bulletproof part of my vest" (Palahniuk IM 284-285).

This shows how Denzin's analysis of postmodern society as a dramaturgical society, one in which, "Art not only mirrors life, it structures and reproduces it" (x), has been taken to the extreme. Here the already blurred line between art and life has been erased to play out the drama of Evie's staged, play-acted life. This example goes even further than erasing the line between art and life. This is what Buadrillard's theory of simulation is elaborating:

...Feigning or dissimulation leaves the reality principal intact: the difference is always clear, it is only masked; whereas simulation threaten the difference between "true" and "false," between "real" and "imaginary" (171).

As the novel shows, the line between real and imaginary is beyond defenseless as Brandy comes up with the story of these character's lives. For Evie, it does not matter whether her life is a staged simulation, real, imaginary, true, or false, just as long as it is not boring. If postmodern society is voyeuristic, then Evie will give society something to grab its gaze ${ }^{46}$.

Evie, like the other characters, has realized that society is constraining and defining, so she decides rather than be a passive observer-the voyeur-who gazes at representational reality on TV and movie screens, she will go to the sound stage mall-recreated habitat-and be the

\footnotetext{
${ }^{46}$ Meanwhile, the audience gets trapped into being the voyeurs of these scenes. This is described in the novel when Shannon is talking about working on the infomercial with Evie, the audience is looking slightly off and to the right of the stage to where the monitors are: "It's eerie, but what's happening is the folks are staring at themselves in the monitor staring at themselves in the monitor staring at themselves in the monitor, on and on, completely trapped in a reality loop that never ends" (Palahniuk IM118). This is what is described by Denzin: "Some of these productions, like 'neo-TV' (Echo, 1984), take themselves and their participants as their own subjects, turning the camera on themselves, as when the camera in a TV talk show pans the audience... The audience, in effect, watches the production of a production, the traditional boundary between film and text and viewer is erased in such moments" (Denzin 11). The reader of the novel watches the production of the drama of these characters' lives as they play out in the novel, and the reader is left with the blurred line between the simulation of events and what actually happened. For instance, the climax of the book was all staged and pre-planned, down to the shooting of Brandy. And as the reader, we find out that the climax was a staged production in the novel, and we know that the author, Chuck Palahniuk, thought out and planned the climax, "Thus [the] double and triple reflexivity... reflects just how far the simulational hyperreal mode of experiencing reality has gone in the contemporary age" (Denzin 11).
} 
object of the gaze of the voyeuristic observer. And in her more personal life-her home life: family, friends, marriage, etc-she will create her own story to play act and keep herself entertained $^{47}$.

${ }^{47}$ Evie is constantly looking to keep herself entertained as her idea for a remake of Cinderella shows. Evie's version has the animals giving Cinderella plastic surgery and Cinderella starts off as a boy. In a sense, this is Evie's story: her family (the wicked stepmother) does not really love her, so she gets a makeover and goes to the ball. Only in Evie's ball there is a fire, a shooting, and her "prince charming" (the groom), runs off with Manus to have sex in a closet, but nonetheless, a postmodern fairy tale. A fairy tale that inverts the normal fairy tale indoctrinating message. Moreover, the idea of being entertained runs throughout the novel as all the characters not only want to break out of societal hegemonic discourse but also, plainly, like the drama of going against society. As Shannon says, "I've developed a pretty big jones for drama" (Palahniuk IM 14) when she is setting the scene at the beginning of the novel. To further illustrate this point, one just has to look at how Shannon describes events in terms of being a drama being acted out; for example, "This is everyone's cue to look at me" (Ibid.). 


\section{Chapter Four: Manus Kelly}

\section{“Fuck," Manus says, "the damn tooth fairy" (Palahniuk IM 213).}

Manus is an emotional wreck throughout the novel because his identity has not been fixed, but he will come to realize how his identity not being fixed leads to more freedom in defining identity on his own terms rather than by societal terms. His identity has been threatened because his family, which as he states is his model for God, has given him his inheritance and all his childhood belongings - things from his past that, in a sense, define who he is. Furthermore, he has been fired from his job because he can no longer attract male 'johns' to solicit him for lascivious sexual intentions. Also, his attitude towards relationships leaves him undefined as he goes from men to women to transvestites to wanting men in an effort to merely prove that he is desirable.

Manus spends a lot of time thinking about parents and God, which goes along with God, the Father, but Manus realizes how both ideas (God the Father, and one's mother and father) are constructs that like the story of the tooth fairy have been handed down to generation after generation. Part of Manus's identity are these things from his past which his parents have given him, but another part of his identity is also his family, and it turns out Manus's family does not care about handing down their heritage to Manus, which leaves him without an identity. His past, rather than the birthright or inheritance it should be, is, "...full of all this shit and heirlooms that nobody else wants"" (Palahniuk IM 212). If an heirloom is something passed down from generation to generation, then it is the Kelly's identity that is "shit" that "nobody else wants," including Manus because Manus, at this moment, wants to break free form fraudulent stories of identity and the past and indoctrination (fuck the tooth fairy). Manus refuses his legacy because he wants to break out of the defining constraints of society: 
...Manus reaches back and grabs another something. A silver candlestick. "This is my legacy," Manus says. Pitched overhand into the darkness, the candlestick turns end over end, silent the way you imagine satellites fly (Ibid.).

Manus throws his identity, including his baby material (bronzed shoes, first teeth, etc.), including his birth certificate, off over a cliff and "out of existence" (Ibid. 213). Manus is literally throwing away his "existence" which is wrapped up in identity, but Manus will go in search of a new identity. Manus is breaking free form his parents' ideas for him and metaphorically from God's plan for him. As he says, "First...your parents, they give you life, but then they try to give you their life" (Ibid. 210). Manus does not want that life, nor does he want the life that is "given" to him by God; as he makes the comparison of God to parents, "...your parents are sort of like God. Sure, you love them and want to know they're still around, but you never really see them unless they want something" (Ibid. 212). This all comes after a misunderstanding between Shannon and Manus, but the result is that Manus is now forced into the Brandy Reincarnation Program:

Brandy says, "Listen, I don't want to know who you are, but if you could be anybody, who would you be?"

"I'm not getting old, that's for sure" Manus says, shaking his head. "No was." Arms crossed, he rocks heel-toe, heel-toe.

“Then you're Mr. Denver Omelet," Brandy says (Ibid. 215).

The problem is that Manus goes from society and God defining him to Brandy defining him, and unlike Shannon or Evie, who are aware of Brandy's defining hand in their constantly 
changing made up identities, Manus is being drugged and is unaware of Brandy's control ${ }^{48}$. Manus has a new religious experience while on his road trip with Shannon and his new Supreme Being, Brandy. This is seen as Brandy reads from her new bible: the biography of Rona Barrett, and Manus testifies throughout, "Hallelujah,' Seth says, all teared up again." Then again, "'Praise God,' Seth says," and then he gives another Hallelujah before Brandy is finished reading from the book (Palahniuk IM 85).

Since Manus loses his identity given to him by God and society, he spends much of the novel contemplating his identity both in an effort to come up with a new sense of identity that is different from the one he has known his whole life and experiencing emotions that are drug induced. The problem is that he is unknowingly ingesting so many drugs given to him by Brandy and Shannon that none of his contemplations can be said to really be his, yet it can be said that what he thinks is real is close enough to reality if his emotions are read through Buadrillard's concept of simulation. Furthermore, the simulation here is a simulation of a simulation of a simulation. On one level, Manus's feelings are simulated through the hormones that Shannon and Brandy are giving him, so when he asks, "Don't you think that somehow television makes us God?" and no one answers, and he tears up saying, "Am I the only one who cares about these issues...Am I the only one here in this car who feels anything real," the problem is that this "real" feeling he is talking about is just a simulation created by the hormones being fed to him. Manus elaborates his TV metaphor by explaining that one can sit in on any life and see everything that a person on TV is doing the way God watches people on earth, "And if you believe that we really have free will, then you know that God can't really control us... And since God can't control us...all he does is watch and change channels when He gets bored" (Palahniuk $\underline{\mathrm{M}}$ all quotes from 79-80). This is the ultimate hyerreal: God watches us, we watch other people on TV, people on

\footnotetext{
${ }^{48}$ Arguably, though, society having control over Manus is worse than Brandy having control over him because society will delude him his whole life whereas Brandy will open up the possibilities of his identity by teaching him to constantly be changing and challenging the discourse.
} 
TV watch people on TV, and then moreover, we, the reader, are reading a fictional story about a constructed story about God watching us, us watching TV, people on TV looking off to the side to see themselves watch themselves watch themselves.

It is with these simulated thoughts and emotions that Manus is finally able to break free from the past of his identity, and his ideas about God and parents and society in order to accept his new God, "The Princess B. A. is God" (Ibid. 83). It is the Princess B. A. who will teach Manus how to keep changing in order to not be totalized. Shannon explains the frustration that comes with constantly moving identity forward:

Some days, I hate it when Brandy changes our lives without warning. Sometimes, twice in one day, you have to live up to a new identity, A new name, New relationships. Handicaps. It's hard to remember who I started this road trip being (Palahniuk $\underline{\mathrm{IM}}$ 65).

Manus has realized that nothing is promised in the future and that the future threatens identity, "When did the future switch from being a promise to being a threat" (Ibid. 103). This is a scene in which the characters have gone to the Seattle Space Needle to go see what the future was supposed to look like, but the future they see there is a run down and bleak one. The future the Space Needle represents is the result of thematizing and putting into words identity. Once put into words, in this case, once the future has been actualized, it begins to deteriorate because it is now a rigid fix "thing" that is seen and graspable. Manus writes on post cards that will be thrown out the top of the Space Needle in order to get people thinking. The Space Needle becomes the symbolic location of the dangers of trying to create an unchangeable and fixed future, which is why the future has turned into a threat. In other words, this version of the future, the run down and archaic Space needle is the future because it is what was put into words.

Manus goes on to write, "You have to keep recycling yourself' (Ibid. 104). This shows how he has come to realize how identity is a constantly moving ahead of itself, a constant 
recycling. He also writes, "Your birth is a mistake you'll spend your whole life trying to correct" (264). This statement echoes Manus's feelings after having his birth thrown back at him by his family. The mistake is not the birth, but rather the indoctrination into a society that defines him arbitrarily. Especially as a bisexual man who goes with both men and women, Manus is left in a grey area in terms of how he is defined by society. What is meant by spending your whole life trying to correct your birth, I believe, is that your whole life will be a constant moving forward and fulfilling of potentiality. Your whole life, identity, is a never static, fixed state, but one that since birth, does not stop moving ahead of itself. The mistake of birth is that since that moment one is indoctrinated into society. The mistake that must be corrected is to think outside of totalizing terms, as much as that is possible.

The reason for Manus to feel that his birth is a mistake that he will spend his whole life trying to correct and for the feeling of having to constantly keep recycling himself can be seen in the structure of being that Heidegger outlines as an always-already being in the world thrown ahead of itself into its potentiality, but being thrown ahead of itself, Dasien still has to deal with the past while always having the potentiality of the end ahead of itself. Heidegger describes it as such:

The ahead-of-itself presented itself as a not-yet. But the ahead-of-itself, characterized in the sense of something outstanding, revealed itself to our genuine existential reflection as being toward the end, something that in the depths of its being every Da-sein is (Heidegger 292, italics in original).

This passage from Heidegger is saying the same thing as Manus; Dasien is always a moving forward, so the mistake that is being corrected is the mistake of falling into a complacent attitude about life. An attitude that easily finds comfort in thinking of its existence as a nonchanging thing. But Manus and Heidegger are saying that one's being is always a towards: a 
towards the future, towards others, and towards death/finality, thus one has to keep 'constantly recycling oneself' in order to fulfill his or her full potentiality.

Death is the final potentiality - it is the possibility that ends all possibilities - and this finality is just one feature of the meaning of Dasein. In death one reaches the end of potentiality, and it is death that gives life meaning and motivation. Life without death would be constant postponement, and for Manus, life without death would mean that he would have more time to fulfill his duties as a vice operative - that he would never age or loose his looks and thus never contemplate his life the way he is contemplating his life now and, therefore, never change. Beingtowards-death shows how Dasein is rooted in care ${ }^{49}$. Care here is meant in two ways: in one sense care is in caring about something, and in another way care is in taking care of things. Care, then, is what makes Dasein take up certain projects. Manus has certain projects he wants to take up, so the mistake of life is to be caught in inauthentic living which will keep Manus from fulfilling the potentiality of these projects. Manus has realized how the constantly changing identities help him from falling into inauthentic living. This is the angst, which Manus feels in not being able to fulfill his job duties any longer. While at the same time, it is this care of Dasein, this constantly thrown forward of being that helps Manus find new strength in constantly subverting the dominant discourse.

Manus's job defines him through his appearance and validates his appearance. As Manus gets older, he is unable to do his job because his appearance changes, and Manus tries to change with it, "So now he'd have to start conversations. Talk. Be funny. Really work at meeting guys. Develop a personality..." (Palahniuk IM 233). Manus tries to develop his identity in these ways because his job is a project he has taken up and is part of his potentiality, but his job demands that he be able to attract "johns" (solicitors of prostitutes), which Manus does not do anymore. When

\footnotetext{
${ }^{49}$ As Heidegger explains, "The being of Da-sein means being-ahead-of-oneself-already-in (the world) as being-together-with (innerwordly beings encountered). This being fills in the significance of the term care, which is used in a purely ontological and existential way" (180).
} 
Manus finally gets fired from his "special vice operative" job, he has to validate himself by engaging in sexual intercourse with whomever he $\mathrm{can}^{50}$, which is what leads to his cheating on Shannon with Evie. His world falls apart finally when his family, in a way, disowns him and gives him his inheritance because they do not want it. With nothing left to validate his identity, Manus sleeps around, or as Shannon puts it, “...his driving need to prove he can still pee on every tree" (Ibid. 239). Manus's way of challenging the dominant discourse will be through sexuality, which leads to him playing with his gender the way Brandy/Shannon does, "Jump to some day down the road soon when Manus will get his breast" (Ibid. 290).

\footnotetext{
${ }^{50}$ This stems from Manus receiving his validation, and getting his identity from, society. Society has only defined him as a sexual person capable of sexual conquest, and thus Manus gets his identity from his ability to fornicate with both genders, but now with Brandy, his past is just a story, and Manus is now free to be the myriad of aliases that Brandy comes up with for him.
} 


\section{Conclusion: I Know of Only One Duty, and That is to Love.}

\section{What I need now is a new story (Palahniuk IM 296).}

Albert Camus said that he wanted to change people but not the world, which he saw as divine $^{51}$, and it seems that Brandy, Shannon, and the others feel the same way. They do not want to change the world; they just want to change the way people think about the world around them and about the way people are in the world. Chuck Palahniuk, also, does not seem like he wants to change the world but only the story about the world. It is hard to say what these characters achieve by disfiguring themselves and challenging the dominant discourse other than the awareness they have of societal constraints, and they know that by doing these things they will not be easily defined by society any longer.

Although Palahniuk deconstructs society to show how the natural attitude towards the world we have is not essentially natural, he is also giving his readers a story about community and love. The most astute reading of Palahniuk's underlying themes can be seen in Jesse Kavadlo's essay" when he states, "Each novel...egregiously violent even by Palahniuk standards - ultimately proposes that what their characters, and all of us, need is - love" (Kavadlo 6). This is seen in $\underline{I M}$ as the novel ends with Shannon giving up her identity to Brandy. So often people are classified as "giving of themselves" to signify how much they care about community, and arguably there is no better way to express that giveness but to give away identity; especially when one thinks of how long it takes to come up with an identity and how much work is put into that identity. Shannon has worked hard to become a fashion model that can get steady work, and now she will give that over to Brandy so that Brandy can live out her dreams. Presumably, in the process, Brandy will continue to influence others and teach others how society is controlling and defining. She will continue to show how a transgender person can be the object of males' gazes

\footnotetext{
${ }^{51}$ Paraphrased from lecture series with Robert Harrison.

52 "The Fiction of Self-destruction" Chuck Palahniuk, Closet Moralist." Full reference in bibliography.
} 
and desires, and she will continue to subvert the "natural" idea of sexual desires and gender roles. And all this is possible because of the loving gift from Shannon.

Shannon is left looking for something "real," and for her that something real is love in a world of simulacra which moves forward like plot lines in a book or movie, "The fire in Evie's clothes is just more and more every second, and now the plot moves along without you pushing" (Palahniuk IM 273). Shannon chooses love over the radical Baudrillardian postmodern idea of the loss of refrenciality as she states:

Give me a complete late-stage revision of my adult life.

Flash.

Give me anything in this whole fucking world that is exactly what it looks like!

Flash.

Here, again, there is the intertextuality of her feelings being tied into a photographer telling her how to feel and "pose." It also show how, more and more, Shannon nostalgically wishes for something that has a direct, straight meaning, which is why she clings to Brandy. Later, Shannon says:

Give me release.

I'm tired of this world of appearances. Pigs that only look fat. Families that look happy.

Give me deliverance.

From what only looks like generosity. What only looks like love.

Flash (Ibid. 291).

Shannon is tired of empty signifiers, 'things that only look like things.' The only real thing that she can cling to is love and community-the being-with-others, which happens in a 
transcednt, out of language state. Denzin can insightfully comment on what Shannon is going through. He states:

All knowledge is narrative. Today, more than ever in the history of western civilization multiple, local narratives, framed within larger interpretive patriarchal frameworks, daily circulate through the currents of popular culture, from film to soap operas, comic books, popular music, and romance novels. No, the loss of meaning and the mourning come from the very condition that Jameson and Baudrillard have identified. The cultural logics of late capitalism keep the unattainable (the real, the past, romantic love, true happiness) alive, attempting over and over again to reconcile the image with its referent, the concept with the sensible, the transparent with the communicable experience (Denzin 40).

Unable to find any material reality, she finds something real ${ }^{53}$ in the love she has for her brother, Brandy. Shannon, as a model, is surrounded by things that are fake in her work; as the daughter of a farmer who falsely fattens up pigs, she was surrounded by artifice as a child; as the sister of a closeted homosexual, she was surrounded by fake gender roles; and as a friend of Evie, she is surrounded by friends who are not what they seem; and as the girlfriend of Manus, she is surrounded by fake emotions (his fake emotions towards her). All of these things are aspects of identity and the things that influence identity, so it is no wonder that she rebels against these

\footnotetext{
${ }^{53}$ It is important to note that the "real thing" she finds is still something evanescent: love. I would also argue that the whole story she has been telling the reader is an ephemeral discourse, one which the audience can never experience. On one level, the whole story can be seen as made up by Shannon, and it is the story she is telling, itself, that is the gift she gives her brother, Shane. The other way to see the story is that Shane really did die after leaving the house, and the story she has been telling is her way of bearing witness in Derridain terms. Derrida explains how responsible bearing witness has to be done in poetic language, and that poetic language is one that calls attention to itself. Poetic language becomes poetic, "... in the act of its event" (Derrida "Poetic and Politics of Witnessing" 66). Poetic language does not try to pass itself off as saying "this is what happened," but rather, poetic language can be interpreted in different ways such as $\underline{\mathrm{IM}}$. In a sense, it can be said that this story is Shannon's poem, her bearing witness, for her dead brother. It is the meta-meta-narrative about bearing witness to Shane.
} 
things the first chance she gets. Ultimately what Shannon returns to is: love $\mathrm{e}^{54}$. The novel ends in her total devotion and love for Brandy, "Completely and totally, permanently and without hope, forever and ever I love Brandy Alexander. And that is enough" (Palahniuk $\underline{\text { IM } 297) .}$

Chuck Palahniuk has been known as the writer of the book that became the famous movie Fight Club, but I hope that this thesis shows that Palahniuk is more of a satirist as Kavaldo explains, "More than an existential philosopher, however, Palahniuk is an American ironist in the tradition of Mark Twain, Nathanael West, Flannery O'Connor, Vladamir Nabokov, and Don DeLillo" (7). Kavaldo does an excellent job of closely reading Palahniuk and of not taking Palahniuk's fiction in the dogmatic fashion some of Palahniuk's fans have done, which leads critics to condemn Palahniuk for being too violent, too sexist, and too crass. The problem is that the violence is always contrasted by the humanity of his characters. Again, to quote Kavaldo:

A careful reader will, like the narrator [of Fight Club], be left unconvinced by Tyler's sophistry and instead notice that only his language, exemplified by Palahniuk's pumped up, brutally funny style, is powerful. His solutions... are not

The same is true of $\underline{\mathrm{IM}}$, where the reader might side with the drug induced, road trip musings of Brandy's brutal and harsh rebellion against society. Rather than rebel against society in the extreme way Shannon and Brandy do, the reader must remember that there is no getting outside of society, "Anything we want we're trained to want" (Palahniuk IM 259). The reader must also remember that this only looks like rebellion, as Shannon repeatedly explains how things only "look like love, generosity, like she is crying" etc. what they are supposed to be.

\footnotetext{
${ }^{54}$ This is a love not in a traditional totalizing sense. The usual, logocentric attitude towards love is that it is a something or a someone. Whereas in this narrative, the something and someone are constantly changing, and although this love is constantly changing (and cannot be put in words) it is something that Shannon encounters and accepts. The pseudo-religious language in which Shannon declares her love for Brandy shows how the love that is being talked about here, is like faith which is usually described in terms that go beyond language and explainable experience - rather this love is an always-already changing and beyond words discourse.
} 
The point is, to reiterate again, to find community and love in a world where everything is false, and society is all just a copy of a copy, powerless vocabulary, just discourse, and makes you feel like you are severely fingering yourself.

While somewhat overlooked by academia, with the recent adaptation of Choke into movie form, and the recent and strong possibility that $\underline{I M}$ will be adapted into a movie, means that academia will be looking at Palahniuk more closely, again. And what academia will realize is that Palahniuk is a modern author with something to say. He is a writer obsessed with the story. He realizes that it is stories we live by and have always lived by since the beginning of language. It is through stories that we come to understand the world, whether cave-man interpreting the rising sun, or societies outsiders making up a story in which they will be included into community, it is through stories that society lives. 


\section{Works Consulted/Cited:}

Baudrillard, Jean. Jean Baudrillard : Selected Writings. Trans. Jacques Mourrain. Ed. Mark Poster. New York: Stanford University Press, 2002.

Butler, Judith P. Gender Trouble : Feminism and the Subversion of Identity. New York: Routledge, 2006.

Boon, Kevin Alexander. "Men and Nostalgia for Violence: Culture and Culpability in Chuck Palahniuk's Fight Club." Journal of Men's Studies 11, no. 3 (2003): 267-276.

Clark, Michael J. "Faludi, Fight Club, and Phallic Masculinity: Exploring the Emasculating Economics of Patriarchy." Journal of Men's Studies 11, no.l (2002): 65-76.

Denzin, Norman K. Images of Postmodern Society: Social Theory and Contemporary Cinema. London: Sage Publications, 1991.

De Rocha Casado, Antionio. "Disease and Community in Chuck Palahniuk's Early Novels." Stirrings Still 2nd ser. 2 (2005): 105-115.

Derrida, Jacques. Dessemination. Trans. Barbara Johnson. Chicago, IL.: University of Chicago Press, 1981.

---. Of Grammatology. Trans. Gayatri Chakravorty Spivak. Baltimore and London: The John Hopkins University Press. 1997.

---. Positions. Trans. Alan Bass. Chicago, IL.: University of Chicago Press, 1981.

---. Sovereignties in Question: the Poetics of Paul Celan. Trans. \& Ed. Thomas Dutoit and Outi Passanen. Fordham University Pres. New York, NY. 2005.

---. Writing and Difference. Trans. Alan Bass. New York: University of Chicago Press, 1980.

De Saussure, Ferdinand. Course in General Linguistics. Ed. Charles Bally, Albert Sechehaye, and Albert Riedlinger. Trans. An Annotated by Roy Harris. Chicago, IL.: Open Court, 1983.

Eagleton, Terry. Literary Theory: An Introduction. New York: University of Minnesota Press, 1996.

Friday, Krister. "A Generation of Men Without History': Fight Club, Masculinity, and the Historical Symptom." Postmodern Culture 13, no. 3 (2003).

http://www3.iath.virginia.edu/pmc/text-only/issue.503/13.3friday.txt (accessed 19 August 2008).

Harrison, Robert. Entitled Opinion "Jean-Marie Apostolidès on Albert Camus." Lecture series. Stanford University and ITunes U. 12-06-05.

Heidegger, Martin. Being and Time. Trans. Joan Stambaugh. Albany, NY: State University of New York P, 1996. 
Kavadlo, Jesse. "The Fiction of Self-destruction: Chuck Palahniuk, Closet Moralist." Stirrings Still 2, no. 2 (2005): 3-24.

Lyotard, Jean-Francois. The Post-Modern Condition : A Report on Knowledge. Trans. Geoff Bennington and Brian Massumi. New York: University of Minnesota Press, 1984.

Moran, Dermot. Introduction to Phenomenology. London: Routledge, 2000.

Palahniuk, Chuck. Invisible Monsters. New York: W. W. Norton \& Company, 1999.

--. Fight Club. New York: W. W. Norton \& Company, 1996.

---.An Oral Biography of Buster Casey: Rant. New York, NY.: Doubleday. 2007.

---Stranger Than Fiction: True Stories. New York: Anchor, 2005.

Postcards From the Future. Dir. Dennis Widmyer. Perf. Chuck Palahniuk. DVD. Kinky Mule Films, 2003.

Solomon, Jack. The Signs of Our Time: Semiotics: the Hidden Messages of Enviroments, Objects, and Cultural Images. Los Angeles: Jeremy P. Tarcher, Inc., 1988.

The New American Bible. Nashville: Catholic Bible Press, 1987.

Žižek, Slavoj. "An Ethical Plea for Lies and Masochism." Lacan and Contemporary Film. Ed. Todd McGowan and Sheila Kunkle, 173-186. New York: Other Press, 2004. 